\title{
Neuromedin B and Gastrin-Releasing Peptide Excite Arcuate Nucleus Neuropeptide Y Neurons in a Novel Transgenic Mouse Expressing Strong Renilla Green Fluorescent Protein in NPY Neurons
}

\author{
Anthony N. van den Pol, ${ }^{1}$ Yang Yao, ${ }^{1,4}$ Li-Ying Fu, ${ }^{1 \star}$ Kylie Foo, ${ }^{3 \star}$ Hao Huang, ${ }^{1}$ Roberto Coppari, ${ }^{2}$ Bradford B. Lowell, ${ }^{2}$ \\ and Christian Broberger ${ }^{3}$ \\ ${ }^{1}$ Department of Neurosurgery, Yale University School of Medicine, New Haven, Connecticut 06520, ${ }^{2}$ Department of Internal Medicine, Harvard University, \\ Boston, Massachusetts 02215, ${ }^{3}$ Department of Neuroscience, Karolinska Institute, 17177 Stockholm, Sweden, and ${ }^{4}$ Department of Life Sciences, Nankai \\ University, Tianjin 300071, People's Republic of China
}

Neuropeptide Y (NPY) is one of the most widespread neuropeptides in the brain. Transgenic mice were generated that expressed bright Renilla green fluorescent protein (GFP) in most or all of the known NPY cells in the brain, which otherwise were not identifiable. GFP expression in NPY cells was confirmed with immunocytochemistry and single-cell reverse transcription-PCR. NPY neurons in the hypothalamic arcuate nucleus play an important role in energy homeostasis and endocrine control. Whole-cell patch clamp recording was used to study identified arcuate NPY cells. Primary agents that regulate energy balance include melanocortin receptor agonists, AgRP, and cannabinoids; none of these substances substantially influenced electrical properties of NPY neurons. In striking contrast, neuropeptides of the bombesin family, including gastrin-releasing peptide and neuromedin $\mathrm{B}$, which are found in axons in the mediobasal hypothalamus and may also be released from the gut to signal the brain, showed strong direct excitatory actions at nanomolar levels on the NPY neurons, stronger than the actions of ghrelin and hypocretin/orexin. Bombesin-related peptides reduced input resistance and depolarized the membrane potential. The depolarization was attenuated by several factors: substitution of choline for sodium, extracellular $\mathrm{Ni}^{2+}$, inclusion of BAPTA in the pipette, KB-R7943, and SKF96365. Reduced extracellular calcium enhanced the current, which reversed around $-20 \mathrm{mV}$. Together, these data suggest two mechanisms, activation of nonselective cation channels and the sodium/ calcium exchanger. Since both NPY and POMC neurons, which we also studied, are similarly directly excited by bombesin-like peptides, the peptides may function to initiate broad activation, rather than the cell-type selective activation or inhibition reported for many other compounds that modulate energy homeostasis.

\section{Introduction}

Neurons containing neuropeptide Y (NPY) are found throughout the brain, in which NPY plays a number of functional roles. In the hypothalamus, arcuate nucleus NPY neurons are thought to play an important anabolic role in energy homeostasis (Stanley and Leibowitz, 1985; Elmquist et al., 1999; Saper et al., 2002; Schwartz et al., 2000; Seeley and Woods, 2003) and neuroendocrine regulation (McDonald and Koenig, 1993). Hypothalamic injections of NPY increase food intake (Stanley and Leibowitz, 1985).

\section{Received July 11, 2008; revised March 5, 2009; accepted March 8, 2009.}

This work was supported by National Institutes of Health-National Institute of Neurological Disorders and Stroke Grants NS34887, NS48476, NS41454, NS48476, and P01 DK056116; Swedish Research Council Grant 529-20046698; European Neuroscience Institutions Network; NovoNordisk; and Wenner Gren, Petrus and Augusta Hedlund, and Magnus Bergvall Foundations. We thank Y. Yang, V. Rogulin, and J. N. Davis for technical assistance.

*L.-Y.F. and K.F. contributed equally to this work.

Correspondence should be addressed to Anthony N. van den Pol, Department of Neurosurgery, Yale University School of Medicine, 333 Cedar Street, New Haven, CT 06520. E-mail: anthony.vandenpol@yale.edu.

R. Coppari's present address: Department of Internal Medicine, Southwestern Medical Center, Dallas, TX 75390 DOI:10.1523/JNEUROSCI.3249-08.2009

Copyright $\odot 2009$ Society for Neuroscience $\quad$ 0270-6474/09/294622-18\$15.00/0
In the hippocampus, NPY has been suggested as an endogenous anti-epileptic peptide (Colmers et al., 1991); in the cortex NPY is found in many inhibitory GABA neurons that modulate pyramidal cell function. In other regions of the brain, NPY cells play a role in cardiovascular function, emotion, fear, arousal, and cognition (Colmers and Wahlestedt, 1993). NPY generally exerts inhibitory actions via a number of NPY receptors (Y1-Y5) that are expressed throughout the CNS (Chen and van den Pol, 1996; van den Pol et al., 1996; Rhim et al., 1997; Kopp et al., 2002; Fu et al., 2004; Acuna-Goycolea et al., 2005). Postsynaptically, NPY can reduce calcium currents, activate potassium currents, reduce spike frequency, and hyperpolarize the membrane potential. NPY can also act presynaptically, reducing transmitter release (Colmers et al., 1991).

The introduction of green fluorescent protein (GFP) as a reporter gene has offered an experimental opportunity that has greatly aided electrophysiological recording from neurochemically defined neuronal populations (Cowley et al., 2001; van den Pol et al., 2004). This approach is particularly useful for NPY neurons which, despite their overall numbers, are scattered 
throughout brain regions and are not distinguishable by morphological criteria alone. To overcome these issues, others have generated NPY-GFP mice (Pinto et al., 2004; Roseberry et al., 2004); however, the GFP expression in those mice appeared lower than revealed by histochemistry. Here we present a novel line that was made using a large bacterial artificial chromosome (BAC) sequence containing the NPY promoter driving expression of the bright and stable Renilla GFP (rGFP). The large DNA sequence flanking the Npy gene would be expected to preserve the fidelity of the NPY expression pattern. Human codon-corrected Renilla GFP from the sea pansy, a type of soft coral, has been suggested to be brighter and more stable than other variations of green fluorescent protein, and by selection from several transgenic lines, we generated one with high levels of GFP expression in what appear to be most of the known NPY cells in the mouse brain, as corroborated with immunocytochemistry and single-cell reverse transcription (RT)-PCR.

This transgenic mouse was used to investigate the electrophysiological responses of hypothalamic arcuate nucleus NPY neurons to several neuromodulators implicated in energy homeostasis, including melanocortin receptor agonist MTII and antagonist AgRP, hypocretin/orexin, ghrelin, cannabinoids, and bombesin, and its mammalian analogs gastrin-releasing peptide (GRP), and neuromedin B (NMB). GRP and NMB are synthesized in the hypothalamus and by a number of brain regions that project to the medial hypothalamus and have been suggested to play a role in a number of neurological and psychiatric disorders, and may also influence energy and endocrine homeostasis. GRP and NMB generated a greater (excitatory) effect than any other modulatory agent tested.

\section{Materials and Methods}

Generation of Npy-hrGFP BAC transgenic mice

To visualize NPY neurons in the brain, we used the humanized rGFP, codon corrected for human DNA from the original invertebrate codon sequence. The FRT-Kan-FRT cassette from the plasmid pIGCN21 (provided by Dr. N. G. Copeland, National Cancer Institute, Frederick, MD) was amplified by PCR and inserted into the MluI site of phrGFP-1 (Stratagene) generating the vector here called phrGFP-FRT-Kan-FRT. A BAC DNA (clone name $=$ RP24-177I12) containing sequences spanning from 114,423 bp upstream and 28,595 bp downstream of the mouse Npy gene was electroporated into EL250 bacteria (Lee et al., 2001). The hrGFP-FRT-Kan-FRT cassette from the plasmid phrGFP-FRT-KanFRT was amplified by PCR using the following primer set: NPY-GFP- $F=$ 5'-ATAGCTGGAATTGGGACAAAGACGAGCAATCTCAGCATCTCCAAGTCTGAGCCTTCTGTATCCACAGatggtgagcaagcagatcctgaa-3' and NPY-GFP- $r=5^{\prime}$-TCGCCCGGATTGTCCGGCTTGGAGGGGTACCCCTCAGCCAGAATGCCCAAACACACGAGCAGAGATAGAGacaaaatattaacgcttaca-3'. Use of these primers inserts the hrGFP ATG exactly into the Npy ATG and deletes the first 41 bp of the Npy coding sequences. EL250 bacteria bearing the Npy BAC DNA were made electrocompetent and the homologous recombinases were induced according to published protocols (Lee et al., 2001). The hrGFP-FRT-Kan-FRT cassette was then electroporated into EL250 bacteria bearing the Npy BAC DNA and recombined into the Npy BAC DNA. EL250 bacteria bearing the Npy-hrGFP-FRT-Kan-FRT BAC DNA were identified by PCR screening. The FRT-Kan-FRT cassette was removed according to published protocols (Lee et al., 2001). EL250 bacteria bearing the $N p y$-hrGFP BAC DNA without mutation in the hrGFP coding sequences were obtained. These cells were grown to generate the $N p y$-hrGFP BAC DNA that was prepared using a commercially available kit (Qiagen).

The purified DNA was then microinjected into pronuclei of fertilized one-cell stage embryos of FVB mice (Jackson Laboratories) using standard methods (Hogan et al., 1986). Three transgenic mice (founders) were obtained. Brains from the offspring of one of these founders had strong GFP expression that mimicked NPY distribution. Mice from this transgenic line were used for further studies. Genotyping of Npy-hrGFP transgenic mice was performed by PCR using the following primers: NPY-ata-S-F 5'-TATGTGGACGGGGCAGAAGATCCAGG-3', NPYata-S-R 5'-CCCAGCTCACATATTTATCTAGAG-3', and AA33 5'ggtgcggttgccgtactgga-3'. A PCR-positive mouse was outcrossed to Swiss Webster mice, and then cross-bred to generate a homozygous line.

For purposes of comparison, in a few experiments we also used a transgenic mouse (gift from Dr. M. Low, Oregon Health Science Center, Portland, OR) that expresses GFP within the arcuate nucleus selectively in POMC neurons, as described previously (Cowley et al., 2001; Batterham et al., 2002).

Use of mice in these experiments here and below was approved by the Animal Use committees of Yale and Harvard Universities and Stockholm’s Norra Djurförsöksetiska Nämnd.

\section{Anatomical analysis and immunohistochemistry}

Four mice received an intracerebroventricular colchicine injection 24 or $48 \mathrm{~h}$ before perfusion. Colchicine-treated and naive $(n=10)$ mice were anesthetized with an intraperitoneal injection of $0.2 \mathrm{ml}$ of sodium pentobarbital $(50 \mathrm{mg} / \mathrm{ml})$ and perfused via the ascending aorta with $10 \mathrm{ml}$ of Tyrode's $\mathrm{Ca}^{2+}$-free solution $\left(37^{\circ} \mathrm{C}\right)$, followed by $10 \mathrm{ml}$ of fixative $(4 \%$ paraformaldehyde and $0.4 \%$ picric acid in $0.16 \mathrm{~m}$ phosphate buffer, $\mathrm{pH}$ $\left.6.9,37^{\circ} \mathrm{C}\right)$, followed by $50 \mathrm{ml}$ of the same, but ice-cold $\left(4^{\circ} \mathrm{C}\right)$ fixative. The brains were rapidly dissected out, immersed in the same fixative for $3 \mathrm{~h}$ and rinsed for at least $24 \mathrm{~h}$ in $0.1 \mathrm{~m}$ phosphate buffer, $\mathrm{pH} 7.4$, containing $10 \%$ sucrose, $0.02 \%$ bacitracin, and $0.01 \%$ sodium azide. The brains were sectioned on a cryostat (Microm) to $14 \mu \mathrm{m}$ thickness and thaw-mounted onto gelatin-coated glass slides. For immunohistochemical staining, sections were processed by Tyramide signal amplification (TSA; PerkinElmer LAS) immunohistochemistry. Sections were incubated with primary antisera against NPY (Phoenix Pharmaceuticals; 1:16 000, raised in rabbit), agouti gene-related peptide (AgRP; Phoenix Pharmaceuticals, 1:8 000, raised in rabbit), or $\alpha$-melanocyte-stimulating hormone ( $\alpha$-MSH; Millipore; $1: 16,000$, raised in sheep) diluted in PBS containing $0.3 \%$ Triton $\mathrm{X}-100$ at $4^{\circ} \mathrm{C}$ overnight. Sections were rinsed in TNT buffer (0.1 м Tris-HCl, pH 7.5, 0.15 M NaCl, 0.05\% Tween 20), incubated for $30 \mathrm{~min}$ at room temperature with TNB buffer $(0.1 \mathrm{M}$ Tris- $\mathrm{HCl}, \mathrm{pH}$ $7.5,0.15 \mathrm{M} \mathrm{NaCl}, 0.05 \%$ blocking reagent provided in TSA kit) and subsequently with horseradish-peroxidase-conjugated swine anti-rabbit (for NPY and AgRP staining) or rabbit anti-sheep (for $\alpha$-MSH staining) immunoglobulins (Dako) diluted to 1:200 in TNB buffer for $30 \mathrm{~min}$ at room temperature. After a $30 \mathrm{~min}$ wash in TNT buffer, sections were incubated in Tyramide-tetramethylrhodamine (1:100 in amplification diluent, provided in TSA kit) for $10 \mathrm{~min}$ in room temperature, rinsed again in TNT buffer for 30 min and mounted with glycerol containing $2.5 \%$ triethylenediamine (Sigma).

After processing, the sections were examined in a Nikon fluorescence microscope equipped with D480 excitation/D535 emission and D560 excitation/D630 emission filters or in an Olympus IX70 fluorescence microscope. Every tenth section was collected and inspected for neurons with GFP expression. The mouse brain atlas of Paxinos and Franklin (2001) was used for reference and preparation of schematic images. Micrographs were collected with a Hamamatsu ORCA-ER camera and Wasabi software, or with a Diagnostic Imaging Spot digital camera. Confocal laser scanning micrographs were captured on a Zeiss LSM410 microscope or an Olympus Fluoview 300. Micrographs were processed in Adobe Photoshop and adjusted for brightness and contrast of a whole micrograph.

\section{Single-cell RT-PCR}

The single-cell RT-PCR method of the present study was similar to that reported previously by Kang et al. (2004) with minor modification. Briefly, the cell contents from each neuron were aspirated into a sterile glass micropipette prefilled with 5-6 $\mu$ l of DEPC-treated water. This solution was then expelled into a PCR microtube in which cDNA synthesis was performed using the SuperScript III Reverse Transcriptase kit (Invitrogen) according to the manufacturer's instructions. First, an $8 \mu \mathrm{l}$ solution containing $1 \mu \mathrm{l}$ of each gene-specific oligo $(2 \mu \mathrm{M})$ and $1 \mu \mathrm{l}$ of dNTP mix (250 mM) in DEPC-treated water were added to each micro- 
tube and incubated at $65^{\circ} \mathrm{C}$ for $5 \mathrm{~min}$, then cooled on ice for $1 \mathrm{~min}$. The gene-specific oligos used were the reverse primers described in the PCR procedure below. Next, $4 \mu \mathrm{l}$ of $5 \times$ first-strand buffer, $1 \mu \mathrm{l}$ of $0.1 \mathrm{M}$ DTT solution, $1 \mu \mathrm{l}$ of SuperScript III RT $(200 \mathrm{U} / \mu \mathrm{l})$ and $1 \mu \mathrm{l}$ of RNaseOUT $(40 \mathrm{U} / \mu \mathrm{l})$ were added to each microtube and incubated at $53^{\circ} \mathrm{C}$ for 60 min followed by a heat inactivation step at $70^{\circ} \mathrm{C}$ for $15 \mathrm{~min}$. Finally, $1 \mu \mathrm{l}$ of RNase $\mathrm{H}(2 \mathrm{U} / \mu \mathrm{l})$ was added to each microtube and incubated at $37^{\circ} \mathrm{C}$ for $20 \mathrm{~min}$ with the final single-cell cDNA products being stored at $-20^{\circ} \mathrm{C}$ until use.

All PCRs were performed using an iCycler thermocycler (Biorad) and the Expand High Fidelity PCR kit (Roche Diagnostics) according to the manufacturer's instructions. Each PCR used $5 \mu \mathrm{l}$ of single-cell cDNA product for template and one pair of gene-specific primers $(30 \mathrm{pmol})$ in a total volume of $50 \mu \mathrm{l}$ and was thermocycled 35 times with an extension time of $45 \mathrm{~s}$. Amplified products were run on 1.5\% agarose gels and visualized using ethidium bromide. Gene-specific primer pairs were designed to amplify mouse $\beta$-actin, NPY, AGRP, GRP-receptor, and NMBreceptor cDNA sequences based on GenBank accession numbers, NM_007393, NM_023456, NM_007427, NM_008177 and NM_008703, respectively, using Oligo Primer Analysis Software version 6.89 (Molecular Biology Insights). A minimum of $550 \mathrm{bp}$ of intronic sequence was spanned in the design of all amplicons to easily distinguish cDNA amplification products from any that might arise from the amplification of genomic DNA.

A single round of PCR (35 cycles) was used in the amplification of $\beta$-actin, NPY and AGRP and a second (nested) round (30 cycles) was used for detecting GRP-receptor and NMB-receptor cDNA. The following list details the target gene, annealing temperature, amplicon length and primer sequences for each PCR. $\beta$-Actin: $56.7^{\circ} \mathrm{C}, 523 \mathrm{bp}$, forward (F) 5'-GCC AAC CGT GAA AAG ATG AC-3', reverse (R) 5'-CAA CGT CAC ACT TCA TGA TG-3' . NPY: $54.7^{\circ} \mathrm{C}$, 294 bp, F $5^{\prime}$-CAC GAT GCT AGG TAA CAA G-3', R 5'-CAC ATG GAA GGG TCT TCA AG-3'. AGRP: $57.8^{\circ} \mathrm{C}, 406$ bp, F 5'-CTG ACT GCA ATG TTG CTG AG-3', R 5'-CAA CAT CCA TTG GCT AGG TG-3'. GRP-receptor: (initial) $55.2^{\circ} \mathrm{C}, 353 \mathrm{bp}, \mathrm{F} 5^{\prime}$-AGA TCT TCT GCA CGG TCA AG-3', R 5' -GTC AGA AAA CAC AGC CTC TG-3'; (nested) $52.8^{\circ} \mathrm{C}, 297 \mathrm{bp}, \mathrm{F} 5^{\prime}$-TGC GAA ACG TGC CAA ACC TG-3', R $5^{\prime}$-ACA TAG AGA CAA TCC AGA TC-3'. NMB-receptor: (initial) $57.8^{\circ} \mathrm{C}, 258 \mathrm{bp}, \mathrm{F} 5^{\prime}$-AGC TGG GCT GCA AAC TCA TC-3', R 5' ${ }^{\prime}$ TGC ATG CTG TGA AAC TGC TG-3'; (nested) $53.2^{\circ} \mathrm{C}, 189 \mathrm{bp}, \mathrm{F} 5^{\prime}$-GTT TCT GTG TTC ACT CTC AC-3', R 5'-ATC CAA GCT ACC AAT GCG TG-3'.

In an analysis of receptor expression, RT-PCR of mouse brain samples was performed by first micro-dissecting discrete regions of the mouse brain from $250-\mu \mathrm{m}$-thick brain slices using GFP localization with fluorescence microscopy. Total RNA was then extracted from each sample using the RNeasy Micro kit (Qiagen) and quantified using a NanoDrop spectrophotometer (Thermo Scientific). Twenty nanograms of total RNA were used as template in reverse transcription reactions, as described above, and $2 \mu \mathrm{l}$ of the resulting cDNA products were used as template in the subsequent PCRs. The PCRs for the GRP-receptor and NMB-receptor were performed using the primers and conditions used for the initial round of single-cell PCR described above.

\section{Electrophysiology}

Preparation of hypothalamic slices. Experiments were performed on hypothalamic slices $(250-350 \mu \mathrm{m})$ obtained from NPY-GFP transgenic mice described here. Two- to 6-week-old mice maintained in a 12/12 h light/dark cycle were given an overdose of sodium pentobarbital (100 $\mathrm{mg} / \mathrm{kg}$ ) during the light part of the cycle (11:00 A.M. to 4:00 P.M.). Their brains were then removed rapidly and placed in an ice-cold, oxygenated $\left(95 \% \mathrm{O}_{2}\right.$ and $5 \% \mathrm{CO}_{2}$ ) high-sucrose solution that contained (in $\left.\mathrm{mM}\right) 220$ sucrose, $2.5 \mathrm{KCl}, 6 \mathrm{MgCl}_{2}, 1 \mathrm{CaCl}_{2}, 1.23 \mathrm{NaH}_{2} \mathrm{PO} 4,26 \mathrm{NaHCO}_{3}$, and 10 glucose, $\mathrm{pH} 7.4$ (with an osmolarity of 300-305 mOsm). A block of tissue containing the hypothalamus was isolated and coronal slices were cut on a Vibratome. After a 1-2 h recovery period, slices were moved to a recording chamber mounted on a BX51WI upright microscope (Olympus) equipped with video-enhanced infrared-differential interference contrast (DIC) and fluorescence. Slices were perfused with a continuous flow of gassed artificial CSF (ACSF; $95 \% \mathrm{O}_{2}$ and $5 \% \mathrm{CO}_{2}$ ) that contained (in mм) $124 \mathrm{NaCl}, 2.5 \mathrm{KCl}, 2 \mathrm{MgCl}_{2}, 2 \mathrm{CaCl}_{2}, 1.23 \mathrm{NaH}_{2} \mathrm{PO}_{4}, 26 \mathrm{NaHCO}_{3}$, and 10 glucose, $\mathrm{pH}$ 7.4. Bath temperature in the recording chamber was maintained at $35 \pm 1^{\circ} \mathrm{C}$ using a dual-channel heat controller (Warner Instruments). Neurons were visualized with an Olympus Optical $40 \times$ water-immersion lens.

Patch-clamp recording. Whole-cell current- and voltage-clamp recordings were performed using pipettes with 4-6 $\mathrm{M} \Omega$ resistance after being filled with pipette solution. The pipettes were made of borosilicate glass (World Precision Instruments) using a PP-83 vertical puller (Narishige). For most recordings, the composition of the pipette solution was as follows (in mM): $130 \mathrm{KMeSO}_{4}$ (or $\mathrm{KCl}$ for IPSCs), $1 \mathrm{MgCl}_{2}, 10 \mathrm{HEPES}$, 1.1 EGTA, 2 Mg-ATP, $0.5 \mathrm{Na}_{2}$-GTP, $5 \mathrm{Na}_{2}$-phosphocreatine, $\mathrm{pH} 7.3$ with $\mathrm{KOH}$ (with an osmolarity of 290-295 mOsm). An EPC10 amplifier and Patchmaster software were used for data acquisition (HEKA Elektronik). PulseFit (HEKA Elektronik), Axograph (Axon Instruments), and Igor Pro (WaveMetrics) software were used for analysis. Liquid junction potential correction was performed off-line. Slow and fast capacitance compensation was automatically performed using Patchmaster software (HEKA Elektronik). Access resistance was continuously monitored during the experiments. Only those cells in which access resistance was stable (changes $<10 \%$ ) were included in the analysis. In analyses of the mechanism of peptide action, to avoid problems associated with desensitization, peptides were applied only once, and statistical comparisons were based on group differences. Both excitatory and inhibitory spontaneous postsynaptic currents were detected and measured with an algorithm in Axograph, and only those events with amplitude $>5 \mathrm{pA}$ were used, as described in detail previously (Gao and van den Pol, 2001). The frequency of action potentials was measured using Axograph as well. Data are expressed as mean \pm SEM. Group statistical significance was assessed using Student's $t$ test for comparison of two groups, and one-way ANOVA followed by a Bonferroni post hoc test for three or more groups. $p<0.05$ was considered statistically significant.

Drugs and drug application. 6-Cyano-7-nitroquinoxaline-2,3-dione (CNQX), DL-2-amino-5-phosphonopentanoic acid (AP5), and bicuculline (BIC) were purchased from Sigma. Tetrodotoxin (TTX) was obtained from Alomone Labs. R-(+)-[2,3-dihydro-5-methyl-3-(4-morpholinylmethyl)pyrrolo[1,2,3-de]-1,4-benzoxazin-6-yl]-1-naphthalenylmethanone mesylate (WIN55,212-2) was obtained from Tocris. Bombesin, GRP, NMB, AgRP, hypocretin-1, and ghrelin were obtained from Phoenix Pharmaceuticals. MTII was obtained from Bachem Bioscience. All drugs were given by large diameter $(500 \mu \mathrm{m})$ flow pipette, directed at the recorded cell, unless otherwise noted. When a drug was not being administered, normal ACSF continuously flowed from the flow pipe. Drug solutions were prepared by diluting the appropriate stock solution with ACSF.

\section{Results}

\section{Immunocytochemical and single-cell RT-PCR confirmation of GFP in NPY neurons}

The arcuate nuclei of transgenic NPY-GFP mice consistently displayed intense fluorescence in cells clustered in the ventromedial portion near the base of the third ventricle. Green fluorescence was apparent throughout the cell soma and in proximal dendrites. In sections immunohistochemically stained for NPY, the $\mathrm{GFP}^{+}$cell bodies were seen enmeshed in a dense NPYimmunoreactive fiber plexus. As a test of the fidelity of GFP expression in NPY neurons, immunostaining and colocalization with GFP was done with antisera against NPY and AgRP, a peptide exclusively colocalized in arcuate NPY neurons. Immunostained red NPY cell bodies also expressed GFP (Fig. 1A-C); similarly, AgRP was found in GFP-positive neurons (data not shown). In mice treated with colchicine to increase peptide concentration in the cell body, NPY immunoreactive cell bodies in the arcuate nuclei of colchicine-treated mice were consistently $\mathrm{GFP}^{+}$, in accordance with previous anatomical data (Broberger et al., 1998). In contrast, $\alpha$-MSH immunoreactivity was observed in a different population of cells distinct from those displaying 


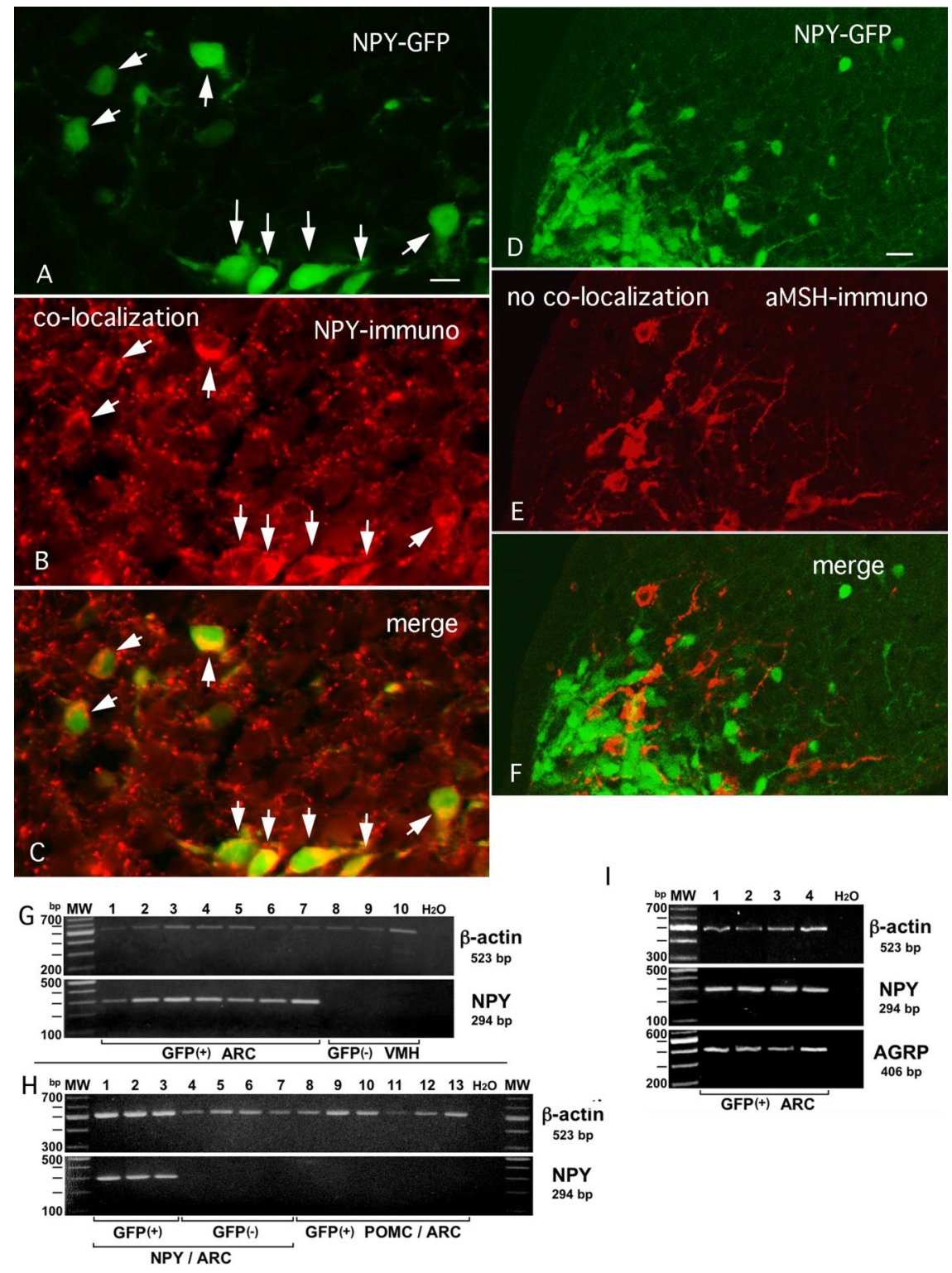

Figure 1. GFP is expressed selectively in NPY neurons. $\boldsymbol{A}$, Micrographs of coronal sections from the arcuate nucleus ( $\operatorname{Arc} ; \boldsymbol{A}-\boldsymbol{C}$ ). GFP expression in the NPY-Renilla GFP mice is green, and immunostaining for NPY is red. C shows the merged image; green GFPpositive cells also show red NPY immunofluorescence. $\boldsymbol{D}-\boldsymbol{F}$, In contrast, immunoreactive $\alpha$-MSH (red) is not colocalized in green neurons expressing GFP. Scale bars: $\boldsymbol{A}, 15 \mu \mathrm{m} ; \boldsymbol{D}, 20 \mu \mathrm{m}$. G, Single-cell RT-PCR was used to test for NPY mRNA expression in GFPpositive cells from the arcuate nucleus and GFP-negative neurons from the ventromedial nucleus (VMH). All GFP-expressing neurons also had NPY mRNA message. In contrast, GFP-negative cells harvested from the VMH showed no NPY mRNA, but were positive for $\beta$-actin used as a control. A final lane used water as an additional control and was negative, as expected. $\boldsymbol{H}$, In additional experiments, three GFP-positive arcuate neurons from the NPY-GFP mouse (lanes 1-3) were compared with GFPnegative neurons from the arcuate nucleus from the same mouse (lanes 4-7) and GFP-positive cells from a different transgenic mouse in which the POMC neurons expressed GFP (lanes 8-13). A final lane served as a water control. Only the three GFP-positive neurons from the NPY-GFP mouse expressed NPY mRNA, whereas the other control cells were all negative. $I$, Four GFP-positive cells from the arcuate nucleus were tested for NPY and AgRP. All four showed mRNA coding for NPY and AgRP, further substantiating the view that the green cells were the NPY neurons.

green fluorescence, and GFP fluorescence was consistently absent from cells showing $\alpha$-MSH immunostaining (Fig. $1 D-F$ ). NPY neurons in the arcuate nucleus (Fig. $1 A-F$ ) were surrounded by NPY immunoreactive axons and showed long and short dendrites labeled with GFP.

As a further test to confirm that GFP expression was selective for cells that synthesize NPY, single GFP-positive neurons were harvested from the arcuate nucleus and tested with single-cell RT-PCR. All seven GFP-positive cells tested also showed mRNA coding for Npy at the expected molecular size, as shown in Figure $1 G$. We repeated this with another nine GFP fluorescent arcuate neurons, and all contained Npy mRNA. In addition, GFP-positive neurons from other brain areas were tested. All eight cells tested from hippocampus, all four from the dorsomedial hypothalamus, and all four from the cortex expressed $N p y$ mRNA. In contrast to this finding that every one of the 32 GFP-positive cells tested also expressed NPY mRNA, all neurons harvested from the hypothalamic ventromedial nucleus $(n=9)$ that showed no GFP expression also showed no expression of $N p y$ mRNA (Fig. 1G). In addition, we used primers for AgRP that colocalizes only with NPY in the arcuate nucleus (Broberger et al., 1998). Four of four GFPpositive arcuate nucleus neurons showed AgRP mRNA expression and NPY mRNA expression (Fig. 1I), confirming that NPY cells expressed GFP.

To test whether NPY mRNA might have been accidentally harvested from nearby cells during the single-cell collection, we also tested four GFP-negative cells from the arcuate nucleus of the NPY-GFP mouse, and also tested six GFP-positive neurons from the arcuate nucleus of a POMC-GFP transgenic mouse; NPY and POMC neurons show overlapping distributions in the arcuate nucleus. All nonNPY-GFP cells from the arcuate nucleus $(n=10)$, including GFP-expressing POMC cells and unidentified neurons with no GFP showed no NPY mRNA (Fig. $1 H$ ), indicating that it was unlikely that neurons other than the single cell harvested contributed substantively to the assay. All neurons used expressed control mRNA coding for $\beta$-actin.

In the cortex (Fig $2 A-D$ ) and hippocampus (Fig. $2 E, F$ ) in which many inhibitory neurons contain NPY, GFPpositive green neurons also showed red NPY immunoreactivity. Similarly, neurons in the hypothalamus outside the arcuate nucleus, for instance in the lateral hypothalamus, that showed GFP expression also showed NPY immunoreactivity (Fig. 2G).

\section{Anatomical regions of GFP expression}

Beyond the arcuate nucleus, fluorescent cells were detected in many structures throughout the brain. Fluorescence was observed throughout the cytoplasm and often in primary dendrites, in some nuclei extending far into the dendritic arborizations. Immunohistochemical staining for NPY revealed GFP signal in almost all NPY-ir cell somata. In general, the intensity of NPY immunofluorescence paralleled the brightness of GFP signal. In addition, GFP-positive terminal fibers were observed in many regions, as detailed below. Cell and fiber densities were categorized as low, medium, or high density (LD, MD, HD, 
respectively) and GFP brightness was designated as low, medium, and high intensity (LI, MI, HI, respectively).

\section{Rhinencephalon}

The olfactory bulb displayed some of the most intense GFP signal in the form of small cell bodies near the mitral layer and exceptionally bright fluorescence in olfactory ensheathing cells within the olfactory nerve layer bordering on the glomerular layer (Fig. 3A). Fluorescent cell bodies and a medium-dense fiber network were also present in all components of the anterior olfactory nucleus.

\section{Telencephalon}

Cerebral cortex. The cerebral cortex displayed consistently high levels of GFP signal, and cells were generally HI with prominent dendritic arbors. GFP-positive cells in the cortex had a general morphology typical of inhibitory interneurons. Fluorescence was observed in all cortical regions, with some relative differences; cell and fiber density were highest in somatosensory cortex, prominent also in visual, motor and prefrontal regions, but less intense in auditory cortex and notably sparse in retrosplenial cortex. The laminar organization was similar between regions: layer I was dense in fluorescent fibers, but low in cell density. In contrast, layer II/III contained the highest accumulation of cells against a brightly fluorescent fiber background. Layer V displayed only occasional cell somata and no fibers, whereas layer VI exhibited the second greatest cell density and prominent fiber plexa. The claustrum harbored MI cells surrounded by MD fibers.

Archicortex. Similar to the neocortex, the hippocampus was also rich in GFP signal (Fig. 3F). Typical NPY interneurons were found interspersed within the pyra-

midal cell layer. In the dentate gyrus, the hilar region contained a high number of cells of varying fluorescence intensities, and was also heavily invested with fibers.

Amygdala. The basolateral nuclei displayed a high-density fiber network with scattered HI multipolar cell bodies (Fig. 3D), whereas the central nucleus was virtually devoid of fluorescent structures. A dense cluster of MI cell bodies was also observed in the basomedial complex, and scattered cells were observed throughout the medial and cortical subnuclei.

Septum. The septal nuclei showed little fluorescence, with the exception of scattered MI cells in the lateral septum and diagonal band. In contrast, the bed nucleus of the anterior commissure contained a HD cluster of MI-HI cells, and MI cells were also observed throughout the medial bed nucleus of the stria terminalis (Fig. 3C).

Striatum. The caudate-putamen contained scattered intensely GFP-positive cells concentrated in the periphery of the nucleus (Fig. $3 E$ ) and embedded in a dense fluorescent fiber net-
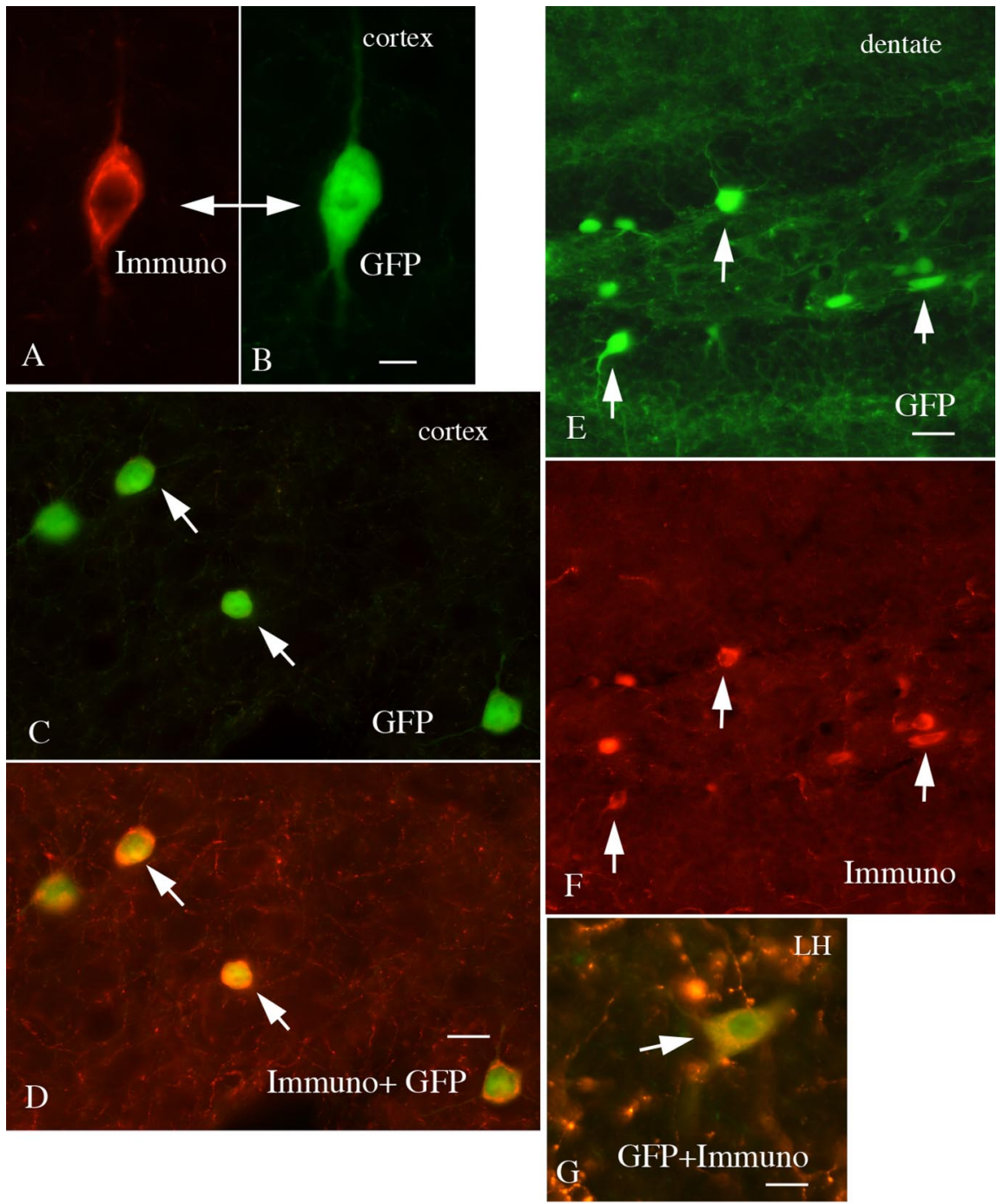

Figure 2. Confirmation of NPY expression in GFP-expressing neurons. $A$, Cortical neuron immunostained with NPY antiserum a labeled red with Alexa 594. B, The same cell expresses strong GFP. Scale bar, $8 \mu \mathrm{m}$. C, Four cortical neurons (arrows) expres

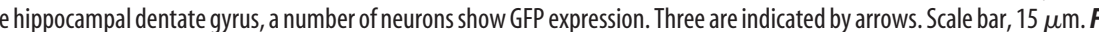
The same cells show red immunolabeling. $\mathbf{G}$, A neuron in the lateral hypothalamus (LH) is green with GFP expression, and also shows red immunostaining. Scale bar, $9 \mu \mathrm{m}$.

work. A similar arrangement but with a higher cell density was seen in the nucleus accumbens (Fig. 3B). In contrast, the globus pallidus was notably lacking in fluorescent structures. The interstitial nucleus of the posterior limb of the anterior commissure (IPAC) harbored abundant HI cells.

\section{Diencephalon}

Hypothalamus. The most robust expression of GFP was found in the arcuate nucleus (Fig. 3I). The dorsomedial nucleus also contained positive cells (Fig. $3 J$ ), but these cells showed less intense GFP expression, and with less cell density. Scattered LI GFP ${ }^{+}$ cells were observed in the medial preoptic area, periventricular region, and in the lateral hypothalamus and perifornical region. No fluorescent cells were observed in the suprachiasmatic, ventromedial, paraventricular (Fig. $3 H$ ) or supraoptic hypothalamic nuclei or in the pituitary gland.

Thalamus. The reticular thalamic nucleus contained numerous cell bodies of MI fluorescence (Fig. 3G). The medial (but not lateral) habenula and the intergeniculate leaflet (Fig. 4A) also 


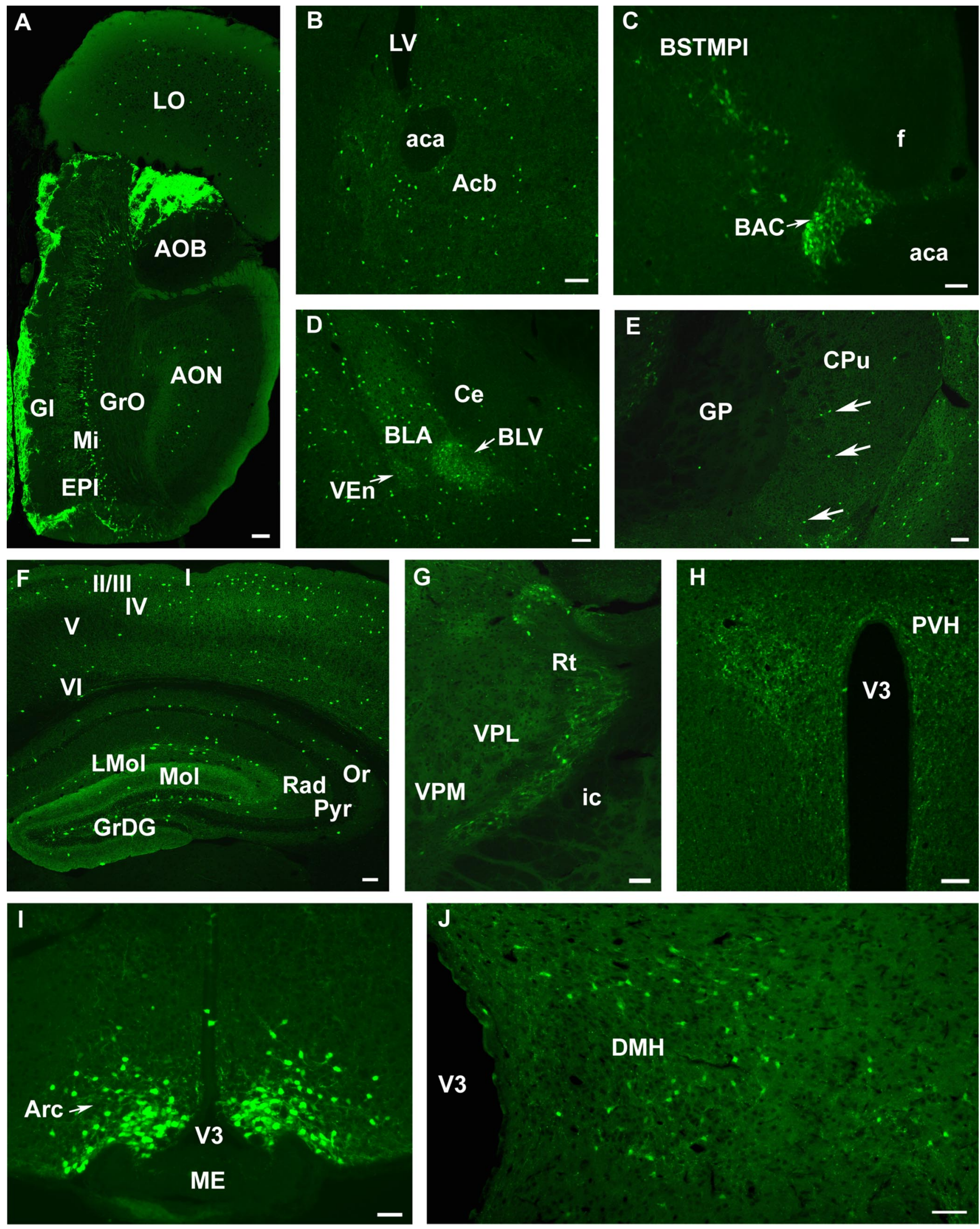

Figure 3. Fluorescence micrographs of coronal sections from brains of Renilla GFP mice showing distribution of fluorescence. $\boldsymbol{A}-\boldsymbol{J}$, Sections shown are from olfactory bulb (A), nucleus accumbens $(\boldsymbol{B})$, septum $(\boldsymbol{C})$, amygdala $(\boldsymbol{D})$, caudate-putamen $(\boldsymbol{E})$, hippocampus and overlying somatosensory cortex $(\boldsymbol{F})$, thalamus $(\boldsymbol{G})$, paraventricular hypothalamic nucleus $(\boldsymbol{H})$, arcuate nucleus $(\boldsymbol{I})$, and dorsomedial hypothalamic nucleus (J). Scale bars: $\boldsymbol{A}, \boldsymbol{B}, \mathbf{D}-\boldsymbol{F}, 100 \mu \mathrm{m} ; \boldsymbol{C}, \mathbf{G}-\boldsymbol{J}, 50 \mu \mathrm{m}$. For abbreviations, see Figure 4. 

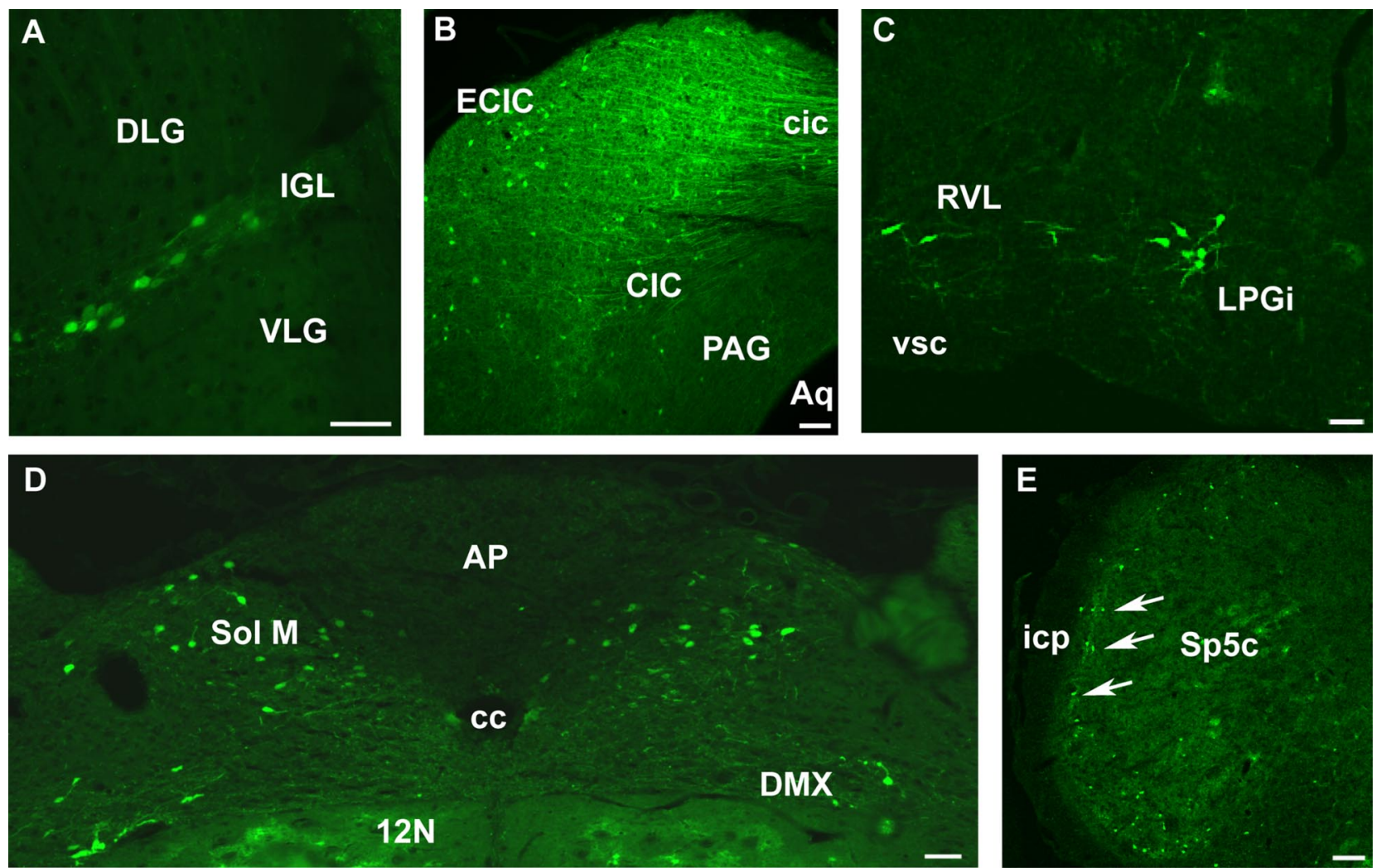

Figure 4. $\quad \boldsymbol{A}-\boldsymbol{E}$, Micrographs of NPY-rGFP in intergeniculate leaflet $(\boldsymbol{A})$, inferior colliculus $(\boldsymbol{B})$, adrenergic $(1$ cell group in ventral medulla oblongata $(\boldsymbol{C})$, nucleus of the solitary tract $(\boldsymbol{D})$, and the lateral caudal medulla oblongata (E). Scale bars: $B, D, 100 \mu \mathrm{m} ; A, C, E, 50 \mu \mathrm{m}$. I-VI, Layers of the cerebral cortex; 12N, hypoglossal nucleus; aca, anterior commissure anterior part; Acb, nucleus accumbens; AON, anterior olfactory nucleus; AOB, accessory olfactory bulb; AP, area postrema; Aq, cerebral aqueduct; Arc, arcuate nucleus; BAC, bed nucleus of the anterior commissure; BLA, basolateral amygdaloid nucleus anterior part; BLV, basolateral amygdaloid nucleus ventral part; BSTMPI, bed nucleus of the stria terminalis medial division posterointermediate part; cc, central canal; Ce, central amygdaloid nucleus; cic, commissure of the inferior colliculus; CIC, central nucleus of the inferior colliculus; CPu, caudate-putamen; DLG, dorsolateral geniculate nucleus; DMH, dorsomedial hypothalamic nucleus; DMX, dorsal motor nucleus of the vagus nerve; $\mathrm{ECIC}$, external cortex of the inferior colliculus; $\mathrm{EPI}$, external plexiform layer of the olfactory bulb; Gl, glomerular layer of the olfactory bulb; $\mathrm{GP}$, globus pallidus; GrDG, granular layer of the dentate gyrus; Gro, granular cell layer of the olfactory bulb; ic, internal capsule; icp, inferior cerebellar peduncle; IGL; intergeniculateleaflet; LMol, lacunosum moleculare layer of the hippocampus; L0, lateral orbital cortex; LPGi, lateral paragigantocellular nucleus; LV, lateral ventricle; ME, median eminence; Mol, molecular layer of the dentate gyrus; $0 r$, oriens layer of the hippocampus; PAG, periaqueductal gray; PVH, paraventricular hypothalamic nucleus; Pyr, pyramidal cell layer of the hippocampus; Rad, stratum radiatum of the hippocampus; Rt, reticular thalamic nucleus; RVL, rostroventrolateral reticular nucleus; SolM, nucleus of the solitary tractmedial part; $S 55 C$, spinal trigeminal nucleus caudal part; $V 3$, third ventricle; VEn, ventral endopiriform nucleus; VLG, ventrolateral geniculate nucleus; VPL, ventral posterolateral thalamic nucleus; VPM, ventral posteromedial thalamic nucleus; vsc, ventral spinocerebellar tract.

harbored HI cell bodies. In contrast, virtually no cell bodies were seen in relay nuclei, although prominent $\mathrm{GFP}^{+}$fibers extended throughout the ventrobasal complex.

Subthalamus. A prominent population of large MI cell bodies with dendrites were seen in the rostral interstitial nucleus of the medial longitudinal fasciculus. A few HI cells were located in the medial extension of the zona incerta.

\section{Parencephalon}

The cerebellum was lacking in GFP signal with the exception of occasional nebulous arborized structures originating in the Purkinje layer and branching into the molecular layer.

\section{Mesencephalon}

The periaqueductal gray area displayed few cell bodies and no fibers, with the exception of occasional LI cells adjacent to the cerebral aqueduct and a cluster of MI cells in the ventrolateral subnucleus bordering on the cuneiform nucleus (Fig. $4 B$ ). Intense fluorescence was seen in the external and dorsal cortices of the inferior colliculus in the form of high-intensity cells and fibers crossing the midline, whereas the central nucleus contained no cells. GFP signal was absent from the superior colliculus complex and the substantia nigra.

\section{Metencephalon}

A small group of MI fluorescent cell somata were seen in the paralemniscal nucleus, the ventromedial tip of the locus ceruleus and in the median raphe, whereas GFP signal was absent in the remaining raphe system.

\section{Myelencephalon}

In the nucleus of the tractus solitarius, high-intensity cells with dendrites were observed primarily in the gelatinous and ventrolateral parts (Fig. 4D). Large HI cell bodies with extensive dendritic extensions were seen in the ventrolateral medulla matching the adrenergic $\mathrm{C} 1$ cell group, and adjacent to the dorsal motor nucleus of the vagus corresponding to the $\mathrm{C} 2$ neurons (Fig. $4 C$ ). Large MI cells were scattered throughout the medullary reticular nucleus. Within the trigeminal complex, small GFP ${ }^{+}$cells were observed in the caudal part of the spinal nucleus lining up along the spinal trigeminal tract (Fig. $4 E$ ).

The position of GFP-expressing NPY cells is depicted in coronal brain sections in Figures 5 and 6.

\section{Periphery}

NPY immunoreactive axons were found in the small intestine and stomach. In the pancreas, some cells showed modest GFP 
A

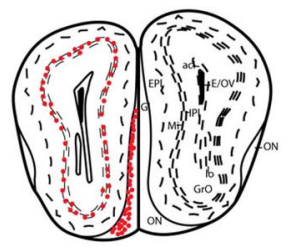

Bregma $4.28 \mathrm{~mm}$

$1 \mathrm{~mm}$

B

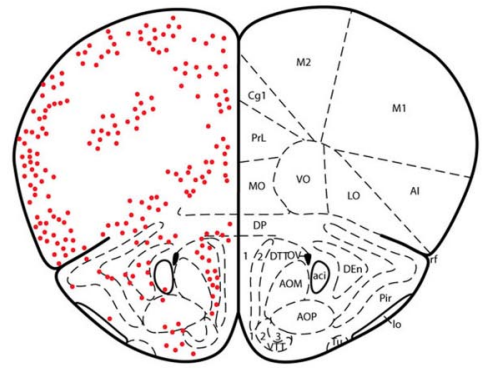

Bregma $2.10 \mathrm{~mm}$

C

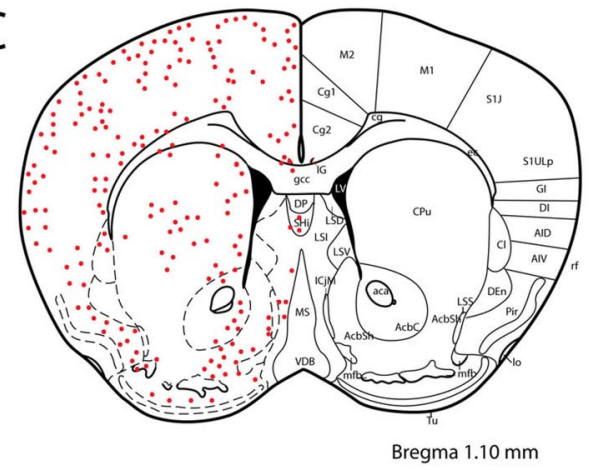

D

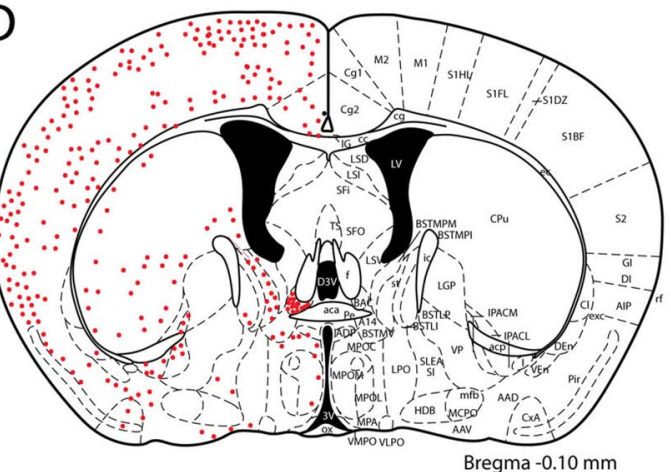

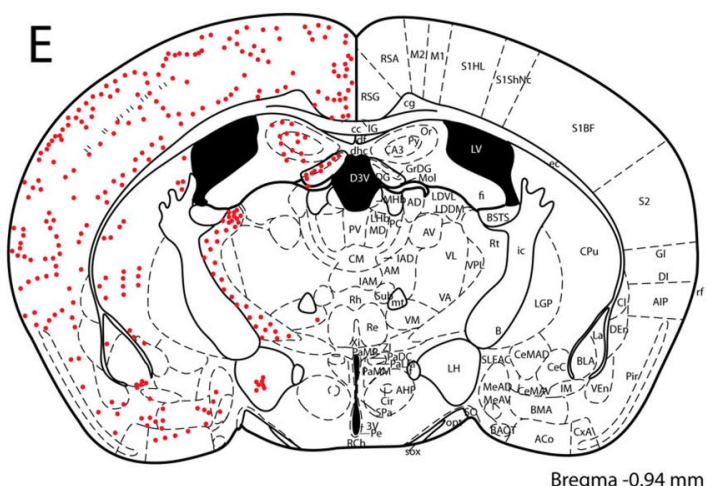
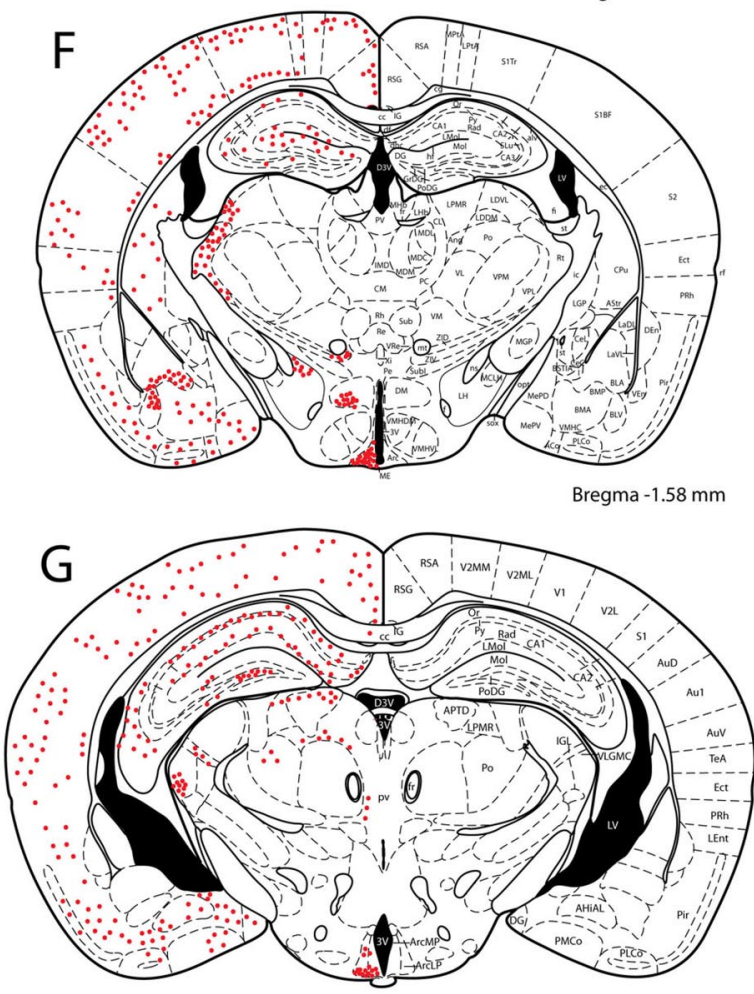

Bregma $-2.30 \mathrm{~mm}$

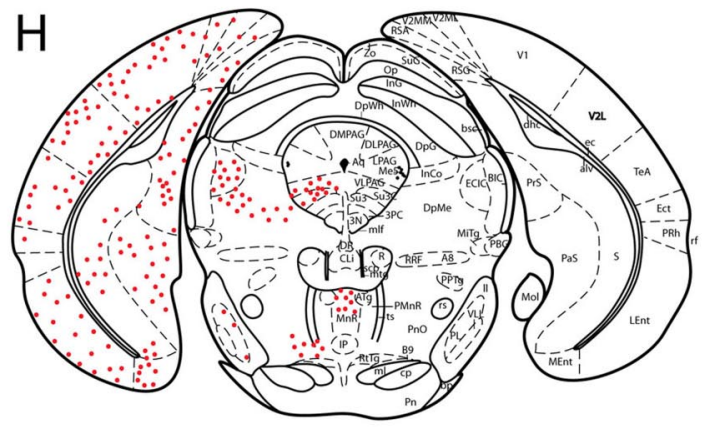

Bregma $-4.16 \mathrm{~mm}$

Figure 5. Schematic illustration depicting the distribution of fluorescent cell bodies-forebrain (filled red circles) in Renilla GFP mice. Scale bar: $\boldsymbol{A}, 1 \mathrm{~mm}$. $\boldsymbol{A}-\boldsymbol{H}$, Anatomical plates taken from Paxinos and Franklin (2001). NPY-GFP cell bodies are found throughout the brain. The left side of each brain section shows the relative density of NPY-GFP cells of this transgenic mouse, and the right shows abbreviations for different brain regions.

expression, and GFP-positive axons surrounded the islets, as described in other species with immunostaining (Myojin et al., 2000).

Axons

GFP expressing axons were found throughout the brain. In the hypothalamic paraventricular nucleus that receives a strong axonal innervation from the NPY neurons of the arcuate nucleus
(Bai et al., 1985; Broberger et al., 1999), strong green fluorescence is found (Fig. 7A) in fibers with no labeling in cells of the nucleus. The same section shows strong red immunofluorescence after immunostaining with NPY antisera (Fig. 7B), indicating that the GFP expression parallels NPY axonal immunoreactivity. In the corpus callosum, GFP-positive axons run parallel to the rest of 

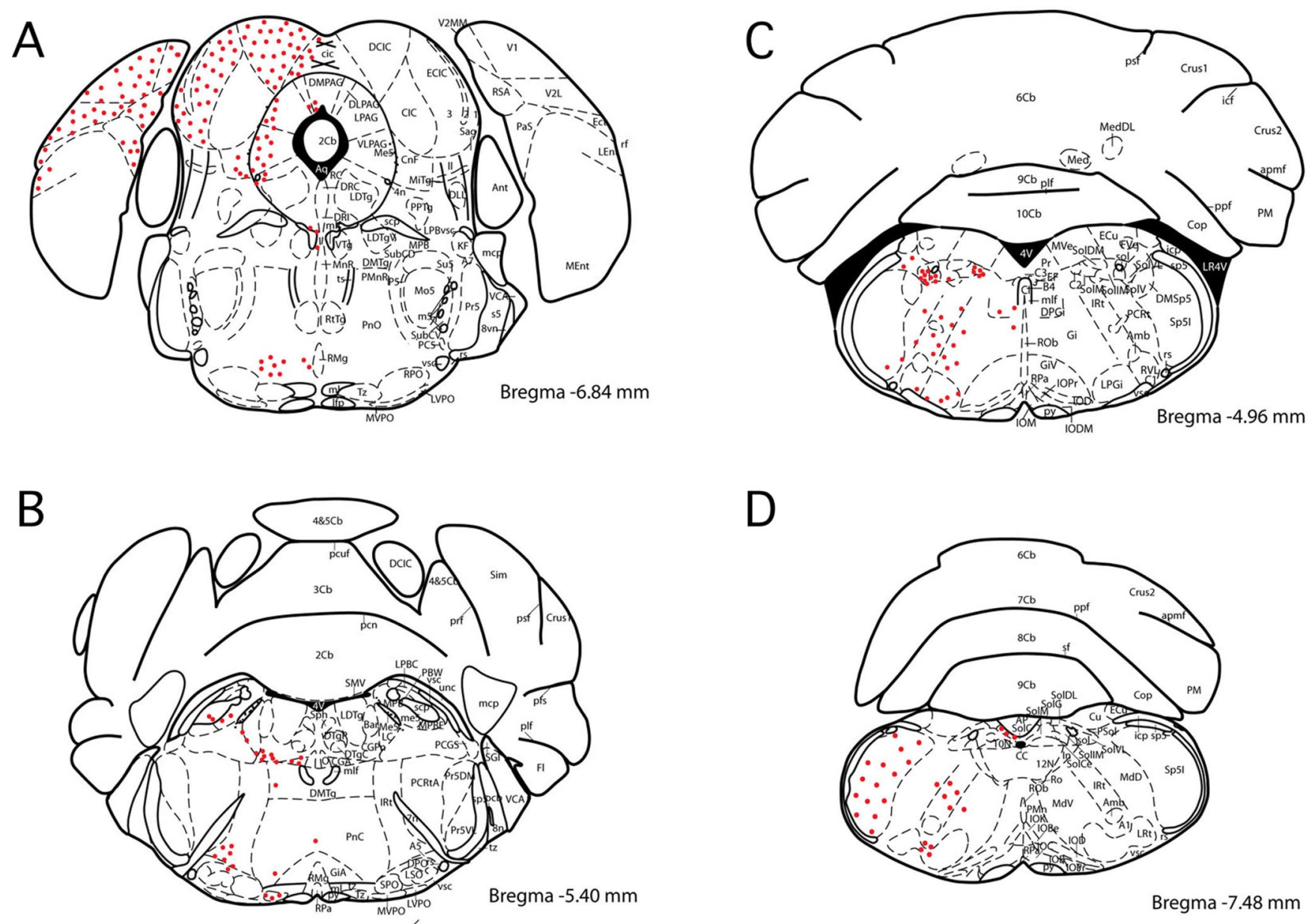

Bregma $-7.48 \mathrm{~mm}$

Figure 6. Schematic illustration depicting the distribution of fluorescent cell bodies-forebrain (filled red circles) in Renilla GFP mice. A-D, Anatomical plates taken from Paxinos and Franklin (2001). NPY-GFP cell bodies are found throughout the brain. The left side of each brain section shows the relative density of NPY-GFP cells of this transgenic mouse, and the right shows abbreviations for different brain regions.

the cortical fibers. In thick sections, GFP fluorescence shows more axons than does red immunostaining (Fig. 7C,D), which may in part be because of penetration of antisera. In addition to axons, granule cell presynaptic dendrites that terminate on mitral cells in the external plexiform layer of the olfactory bulb show GFP fluorescence (Fig. 7E,F). These data suggest that sufficient GFP is synthesized in the cell body to diffuse throughout a large part, or all, of the NPY axons or presynaptic dendrites. In the cerebral cortex, strong axonal fluorescence was found in all layers (Fig. $7 G)$.

A primary rationale for generating and characterizing the NPY-GFP mouse was to use it to study the NPY neurons of the hypothalamus, particularly those in the arcuate nucleus that play a key role in central regulation of energy homeostasis, as described in detail below.

\section{Electrophysiology}

Membrane properties of NPY cells in arcuate nucleus

Using whole-cell recording in hypothalamic slices we characterized the membrane properties of GFP-expressing NPY cells in the arcuate nucleus. Of 28 recorded cells, 27 cells fired spontaneously at $1.4 \pm 0.2 \mathrm{~Hz}$ (range $0.1-4.2 \mathrm{~Hz}$ ). Twelve of the 28 cells showed burst firing (Fig. 8A1), 15 cells fired regularly or irregularly with no bursts (Fig. 8A2), and one cell was silent at rest $(-62.6 \mathrm{mV})$. The mean resting membrane potential was $-56.6 \pm 1.2 \mathrm{mV}$ (range -46.5 to $-72.1 \mathrm{mV}, n=28$ ). The mean spike frequency for nonbursting cells was $1.4 \pm 0.3 \mathrm{~Hz}(0.1-4.2 \mathrm{~Hz}, n=15)$. For bursting neurons, the burst included 10-20 spikes over a period of 2-3 s. Three of nine cells showed continuous firing during a $700 \mathrm{~ms}$ square current pulse of $20-40 \mathrm{pA}$, whereas the others failed to fire continuously during a current injection of $20 \mathrm{pA}$ or 40 pA (Fig. 8B1,B2) and spike failure was apparent (Fig. 8B2). The mean input resistance was $1320 \pm 97 \mathrm{M} \Omega(822-1997 \mathrm{M} \Omega$, $n=13$ ) calculated from the slope of the linear part of the currentvoltage relationship between -60 and $0 \mathrm{mV}$ (Fig. 8C1,C2). In 12 of 13 cells, outward current injections hyperpolarized cells to 40-70 $\mathrm{mV}$ negative to the resting membrane potential; when released from the hyperpolarization, a low threshold spike (LTS) was generated, together with a group of fast spikes (Fig. $8 \mathrm{C1}$ ). The LTS persisted even in the presence of the $\mathrm{Na}^{+}$channel blocker TTX $0.5 \mu \mathrm{M}$, but was blocked by $\mathrm{NiCl}_{2}(200 \mu \mathrm{M})$ (Fig. 8C3), suggesting that it is calcium-dependent.

Synaptic activity was recorded at a holding potential of -35 $\mathrm{mV}$ using KMeSO 4 pipette solution. The upward events represent the IPSCs and the downward events represent EPSCs. Both types of synaptic activity were completely blocked by the glutamate and GABA receptor antagonists AP5 $(50 \mu \mathrm{M}), \mathrm{CNQX}(10 \mu \mathrm{M})$, and BIC $(30 \mu \mathrm{M})$ (Fig. $8 D)$, suggesting that GABA and glutamate account for most of the fast synaptic input to NPY neurons. 

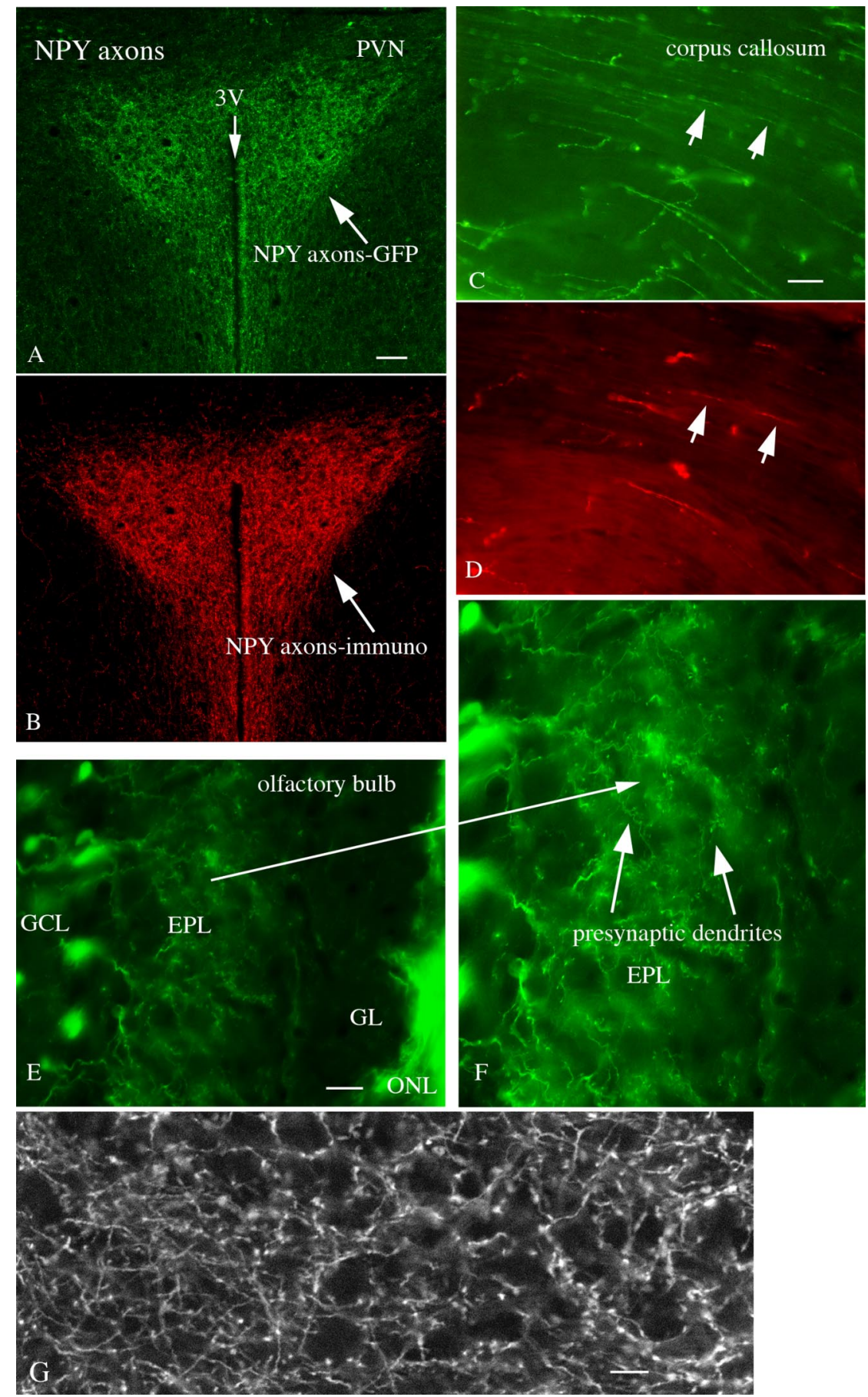

Figure 7. GFP axons and presynaptic dendrites. A, GFP-expressing axons are particularly dense in the hypothalamic paraventricular nucleus. $\boldsymbol{B}$, The same PVN section immunostained red for NPY. Scale bar, $40 \mu \mathrm{m}$. C, In the corpus callosum, GFP-positive axons are seen. $\boldsymbol{D}$, In the same section examined after immunostaining, red immunoreactive axons are seen, but in lower density than seen with GFP. Scale bar, $7 \mu \mathrm{m}$. E, In the olfactory bulb, a subset of granule cells in the granule cell layer (GCL) send dendrites up into the external plexiform layer (EPL). Less GFP is seen in the glomerular layer (GL), but GFP is strong in the olfactory nerve layer (ONL). Scale bar, $20 \mu \mathrm{m}$. $\boldsymbol{F}$, Using a longer exposure, these presynaptic dendrites terminate in the EPL, and have numerous presynaptic boutons. Long arrow shows the same region on both $\boldsymbol{E}$ and $\boldsymbol{F}$. $\boldsymbol{G}$, This scanning laser confocal micrograph shows strong GFP labeling in cortical axons, but not in the large pyramidal cells. Scale bar, $8 \mu \mathrm{m}$.

Little response to AgRP, melanocortin agonists, or cannabinoids

Two neuropeptides prominent in the regulation of energy homeostasis are the proopiomelanocortin peptides, particularly anorexigenic $\alpha$-MSH and the MC3/MC4 receptor agonist MTII, and the antagonist at the melanocortin receptor, AgRP (Cone, 2006). Neither MTII nor AgRP, used at similar or greater concen- trations than used previously (Roseberry et al., 2004; Fu and van den Pol, 2008), changed the activity of NPY cells. After applying MTII (100 nM) for $1 \mathrm{~min}$, neither the spike frequency $[110 \pm 27 \%$ of control $(p>0.05$, ANOVA, $n=6)$ (control $=$ $100 \%)]$, nor the membrane potential $(-1.3 \pm 1 \mathrm{mV} ; p>0.05$, ANOVA, $n=6)$ was changed; $1 \mu \mathrm{M}$ MTII had no effect on membrane potential either $(1.3 \pm 1.1 \mathrm{mV}$; $n=6)$ or spike frequency (114.3 \pm $15.2 \%)$. Similarly, 1 min application of AgRP (100 nM) did not change the spike frequency ( $94 \pm 27 \%$ of control; $p>0.05$, ANOVA, $n=8)$ or membrane potential $(-1.4 \pm 1 \mathrm{mV} ; p>0.05$, ANOVA, $n=8)$ either; $1 \mu \mathrm{M}$ AgRP also had no effect on membrane potential $(0.8 \pm 0.6 \mathrm{mV} ; n=6)$ and no effect on spike frequency (97.9 \pm $13.1 \%, n=6)$. Furthermore, AgRP (100 $\mathrm{nM}$ ) had no effect on excitatory synaptic activity, and did not change the frequency of spontaneous EPSCs (sEPSCs; $4 \pm 11 \%$ decrease; $p>0.05$, ANOVA, $n=6)$. AgRP (100 nM) had no effect on spontaneous IPSCs (sIPSCs; $1.9 \pm 3.3 \%$ decrease) $(p>$ 0.05 ANOVA, $n=5$ ).

Endocannabinoids released from the hypothalamus increase food intake (Cota et al., 2006) and may modulate NPY neurons. Cannabinoids regulate the synaptic activity to arcuate nucleus POMC cells (Hentges et al., 2005). We therefore examined the effect of the type 1 cannabinoid receptor agonist WIN55,212-2 on NPY neuronal activity. WIN55,212-2 (5 $\mu \mathrm{M})$ exerted no detectable effect on membrane potential $(-1.5 \pm 0.4 \mathrm{mV} ; p>0.05, n=5)$ or spike frequency $(+2.0 \pm 3.5 \% ; p>$ $0.05, n=5$ ). Cannabinoid receptors are often located on inhibitory terminals. We therefore examined the effect of WIN55,212-2 on spontaneous IPSCs in NPY neurons. In the presence of WIN55,212-2, the sIPSC frequency and amplitude showed little change (5.4 \pm $4.2 \%$ and $4.0 \pm 6.3 \%$, respectively; $n=5$, $p>0.05$, not significant). We also tested the effect of WIN55,212-2 on spontaneous EPSCs in NPY neurons. In the presence of WIN55,212-2, the sEPSC frequency and amplitude showed little change (3.0 \pm $5.3 \%$ and $5.9 \pm 6.2 \%$, respectively; $n=5$, $p>0.05$, not significant).

\section{Bombesin/GRP/neuromedin B excite NPY neurons}

Bombesin-type receptors are found in the medial hypothalamus; central administration of bombesin suppresses food intake (Merali et al., 1993). Although bombesin probably does not exist in the mammalian brain, closely related peptides of the bombesin family do, and bombesin related peptides have been shown to activate unidentified neurons of the rat 
arcuate nucleus (Lin and Pan, 1994). The effect of bombesin and the bombesinrelated mammalian peptides GRP and NMB on NPY neurons was studied. Bombesin-like peptides reduce feeding when injected into the brain (Tsushima and Mori, 2005); knock-out of one of the bombesin family receptors causes mild obesity (Ohki-Hamazaki et al., 1997). Application of bombesin ( $250 \mathrm{nM})$, a nonselective ligand for bombesin-family receptors (NMB and GRP receptors), depolarized and excited the majority of arcuate NPY neurons (Fig. 9A); a minority of cells tested did not respond to this peptide. Responding cells showed an increased spike frequency sometimes leading to bursts of spikes with an underlying sustained depolarization (Fig. 9A). When data from all 15 cells (responders and nonresponders) were analyzed, bombesin increased the spike frequency by $61.5 \pm$ $14.2 \%$, with a mean depolarization of $5.0 \pm 0.5 \mathrm{mV}(n=15, p<0.05)$. Here and below, when some cells in the group did not respond, we show statistics for the responding cells only, and also for the whole group including nonresponders, thereby eliminating any statistical bias that might result from data selection. Bombesin increased the spike frequency by $75.6 \pm$ $13.0 \%$ in 12 of 15 cells studied, with a mean depolarization of $5.8 \pm 0.4 \mathrm{mV}(n=$ $12 ; p<0.05)$; three cells did not show a change $>20 \%$, the minimum criterion used to deduce an effect.

Similarly, NMB (250 nM) also excited NPY neurons (Fig. 9B). The mean increase in spike frequency was $80.0 \pm 11.5 \%$ in 14 of 16 cells, with a mean depolarization of $6.2 \pm 0.4 \mathrm{mV}(p<0.05)$ (Fig. 9D,E); two cells did not meet a $>20 \%$ change criterion. When all 16 cells were analyzed together, NMB increased the spike frequency by $66.5 \pm 10.6 \%$, with a mean depolarization of $5.6 \pm 0.4 \mathrm{mV}(n=16, p<0.05)$. In some cells, the excitatory effect of $\mathrm{NMB}$, similar to bombesin (Fig. 9A), was associated with an oscillation of the membrane potential caused by a rapid burst of spikes leading to a sustained depolarization (Fig. 9A).

GRP (250 nM) at the same concentration as the other peptides excited fewer NPY neurons. As shown in Figure 9, $C$ and D, GRP $(250 \mathrm{nM})$ increased the spike frequency by $46.0 \pm 12.0 \%$ in 7 of 13 neurons with a mean depolarization of $5.3 \pm 0.6 \mathrm{mV}$. When all 13 cells were included, the spike frequency was increased by $9.2 \pm$ $10.5 \%(n=13, p>0.05)$ after GRP application, with a mean depolarization of $2.6 \pm 0.7 \mathrm{mV}(n=13, p<0.05)$. Thus, all three peptides increased spike frequency (Fig. 9D) and depolarized (Fig. 9E) NPY neurons.

Two bombesin-receptors are differentially sensitive to GRP and NMB. To compare the responses of identified neurons, we tested five additional concentrations $(1,10,100,1000$ and 5000 $\mathrm{nM}$ ) of the two peptides in different sets of NPY neurons. Both GRP and NMB depolarized NPY neurons in a dose-dependent
C1
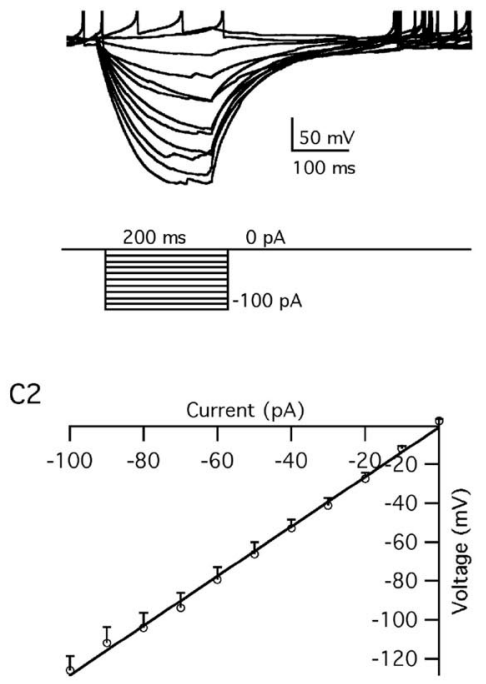

C3 In TTX

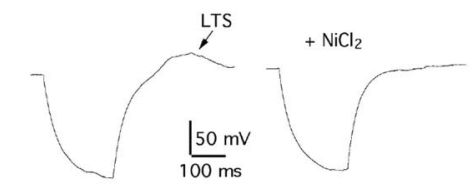

EPSCs+IPSCs

Figure 8. Membrane properties of arcuate nucleus NPY neurons. A1, Spontaneous burst firing of a GFP-expressing NPY neuron at resting membrane potential $(-52.5 \mathrm{mV}$ ). A2, Cell showing spontaneous irregular firing at rest ( $-65.9 \mathrm{mV}$ ). B1, Voltage responses of an NPY neuron to 700-ms-step current injections of 20 pA. B2, A cell failed to fire continuously after the $700 \mathrm{~ms}$ (1) 40 pA. C1, Voltage traces evoked by a step current injection from -100 to 0 pA. C2, Mean current-voltage relationship of 20 GFP neurons. C3, Traces show an LTS evoked when the cell recovered from a hyperpolarization to $-95 \mathrm{mV}$; the recorded at a holding potential at $-35 \mathrm{mV}$ with KMeS04 pipette solution, which were blocked by AP5 $(50 \mu \mathrm{M})$, CNQX $(10 \mu \mathrm{M})$ and $\mathrm{BIC}(30 \mu \mathrm{M})$.

manner. There was no obvious difference in the responses to the two peptides (Fig. 9F, G).

To test further whether the NMB or GRP receptor is found in the arcuate nucleus, we used RT-PCR on tissue isolated selectively from the arcuate nucleus. Both NMB-R and GRP-R were identified in the arcuate nucleus (Fig. 9H). When we tried single-cell RT-PCR analysis, we were unable to consistently identify either receptor. However, our physiological data showing a consistent response to bombesin-like peptides suggested the mRNA was perhaps in too low abundance. We therefore pooled several single NPY cells to increase the amount of template, as described previously (Zhang et al., 2007). In pooled samples, we found a strong NMB-R of the expected molecular weight (Fig. 9I), but found no GRP-R. We did however find GRP-R in other cells of the hypothalamus, indicating the primers were functional, but that GRP-R was either not expressed, or not in detectable abundance in NPY cells. Given the fact that we included a substantial intron spanning sequence, the product is unlikely to be a DNA contaminant, as it would then be expected at a considerably greater molecular weight than found.

Hypocretin/orexin, a hypothalamic neuropeptide involved in 


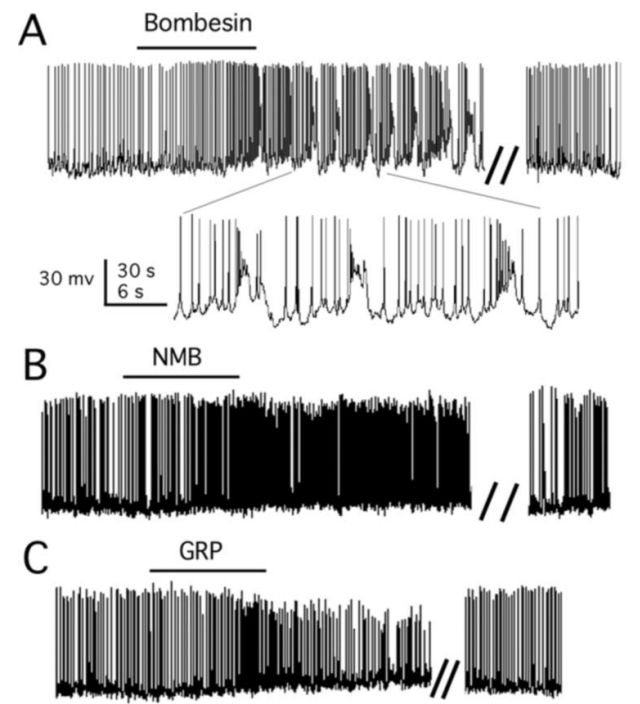

$\mathrm{H}$ arcuate nucleus

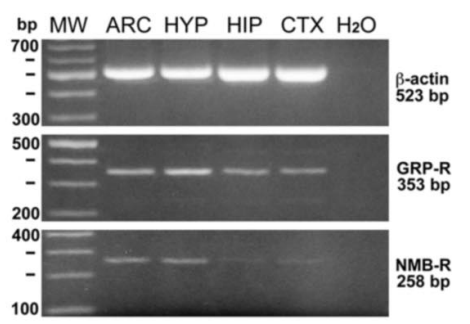

I NPY neurons
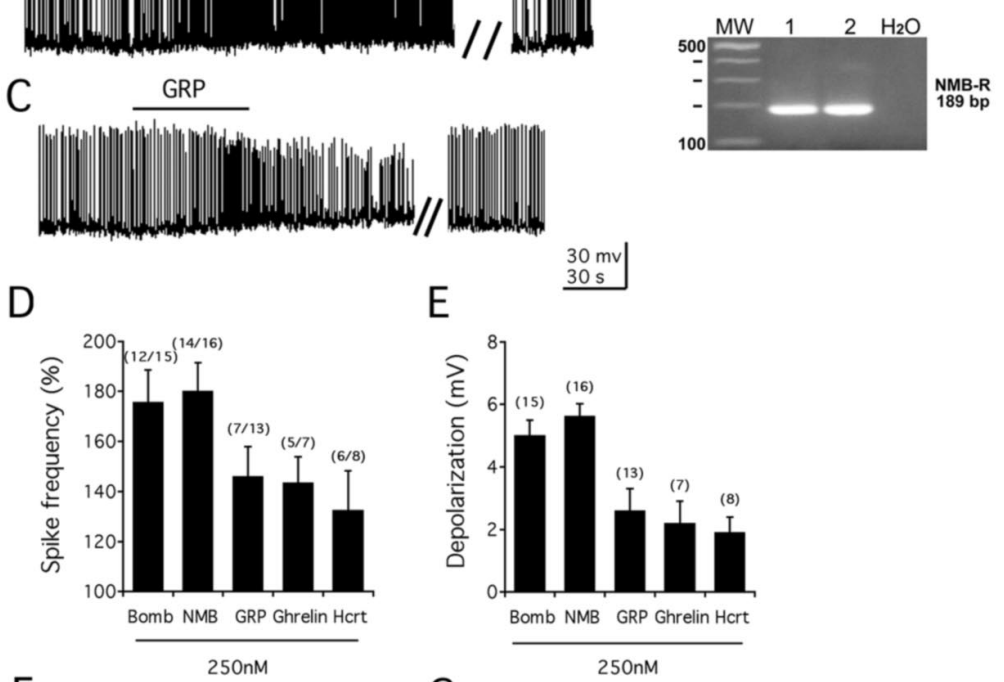

$\mathrm{F}$
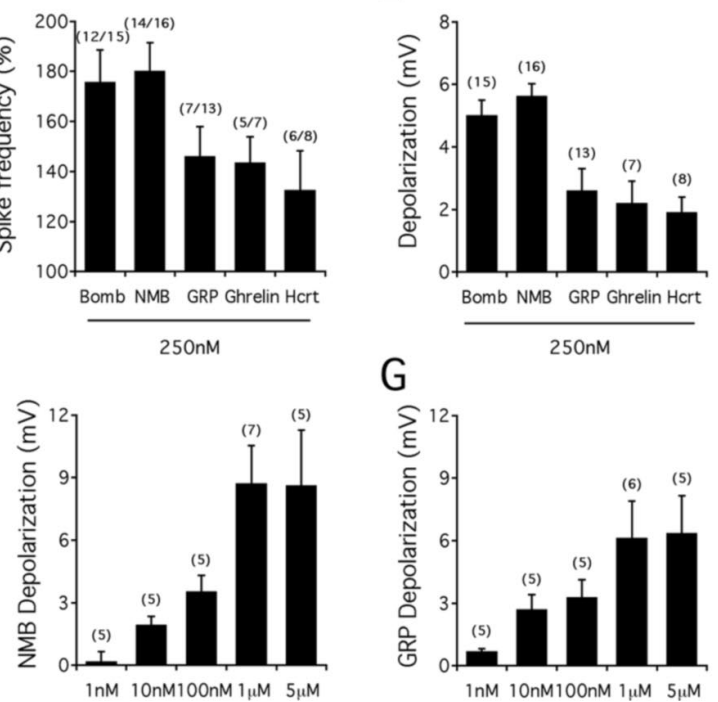

G

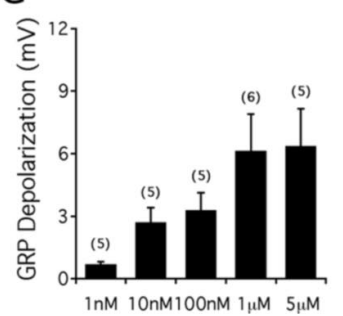

Figure 9. GRP/neuromedin B/bombesin excite NPY neurons. $\boldsymbol{A}-\boldsymbol{C}$, Bombesin $(250 \mathrm{~nm}, \boldsymbol{A})$ and the related mammalian peptides neuromedin $B(N M B, 250 \mathrm{~nm}, \boldsymbol{B})$, and gastrin-releasing peptide (GRP, $250 \mathrm{~nm}, \boldsymbol{C}$ ) increase spike frequency in three different NPY neurons. $\boldsymbol{D}$, Bar graph shows the mean effect of bombesin, NMB, and GRP. For comparison purposes, we also include the magnitude of the response to ghrelin and orexin on the spike frequency of NPY neurons. Bombesin and NMB generate the biggest response of the five peptides tested, all used at $250 \mathrm{~nm}$. Numbers above bars indicate the number of cells that were excited by the peptide over the total cells tested. $\boldsymbol{E}$, Bar graph shows the mean depolarization of the membrane potential evoked by the five neuropeptides. $\boldsymbol{F}$, Bar graph shows the mean depolarization of the membrane potential evoked by the NMB at different concentrations, including 1, 10, 100,1000, and $5000 \mathrm{nm.} \mathrm{G,} \mathrm{Bar} \mathrm{graph} \mathrm{shows} \mathrm{the} \mathrm{mean} \mathrm{depolarization} \mathrm{of} \mathrm{the} \mathrm{membrane} \mathrm{potential} \mathrm{evoked}$ by GRP at a concentration of 1, 10,100,1000, and $5000 \mathrm{~nm}$. The number of cells is shown in parentheses. Error bars indicate SEM. The asterisk indicates statistical significance. $\boldsymbol{H}, \mathrm{RT}-\mathrm{PCR}$ experiment showing arcuate nucleus (ARC), whole hypothalamus (HYP), hippocampus (HIP), and cortex (CTX) with equal amounts of initial template. Both NMB-R (also called BB1) and GRP-R (also called BB2) are expressed in the arcuate nucleus. $I$, Using single cells harvested with a patch pipette, in lane $15 \mathrm{NPY}$ cells were pooled, and in lane 2, $10 \mathrm{NPY}$ cells were pooled to increase the amount of template. NPY cells showed NMB-R expression, as tested by nested RT-PCR.

cognitive arousal and possibly in increasing food intake (Sakurai et al., 1998) has previously been identified as having an excitatory effect on NPY neurons (van den Top et al., 2004; AcunaGoycolea and van den Pol, 2005). To assess the magnitude of the response to bombesin-related peptides, we compared the response to hypocretin at a similar concentration to that used above for bombesin related peptides (250 nM). As shown in Figure 9, $D$ and $E$, hypocretin-1 (250 nM) increased the spike frequency by $32.3 \pm 15.7 \%$ in six of eight neurons with a mean depolarization of $2.5 \pm 0.3 \mathrm{mV}$. When all eight cells were included, the spike frequency was increased by $24.1 \pm 12.7 \%(n=8, p<0.05)$ after hypocretin application, with a mean depolarization of $1.9 \pm 0.5 \mathrm{mV}(n=8, p<0.05)$

Similarly, ghrelin, an appetite-enhancing peptide released by the gut, has been reported to excite NPY neurons (Cowley et al., 2003; Kumarnsit et al., 2003). We applied ghrelin, and recorded both a depolarization and increase in spike frequency. As shown in Figure 9, $D$ and $E$, ghrelin (250 nM) increased the spike frequency by $43.3 \pm 10.5 \%$ in 5 of 7 neurons with a mean depolarization of $3.1 \pm$ $0.6 \mathrm{mV}$. When all 7 cells were included, the spike frequency was increased by $30.9 \pm$ $10.8 \%(n=7, p<0.05)$ after ghrelin application, with a mean depolarization of $2.2 \pm$ $0.7 \mathrm{mV}(n=7, p<0.05)$. When the responses to neuropeptides were compared, bombesin and NMB appeared to exert a greater degree of excitation $(p<0.05)$ than either hypocretin-1 or ghrelin.

\section{Mechanisms of bombesin action on NPY neurons}

To determine whether the mechanism of action was pre- or postsynaptic, we first studied the effect of bombesin on membrane potential in the presence of TTX. With TTX $(0.5 \mu \mathrm{M})$ in the bath, bombesin (250 nM) depolarized the membrane potential by $4.9 \pm 0.5 \mathrm{mV}(n=5, p<0.05)$ (Fig. 10 A). Similarly, NMB (250 nM) in the presence of TTX depolarized the membrane potential by $5.3 \pm 0.3 \mathrm{mV}(n=6$, $p<0.05)$. These results suggest that bombesin and NMB excite NPY neurons through a direct postsynaptic mechanism that is not dependent on TTX-sensitive sodium channels.

To determine whether the excitatory actions of bombesin on NPY neurons were accompanied by increases or decreases in channel opening, as detected by changes in input resistance, we delivered negative current steps (from -70 to $-10 \mathrm{pA}$ over $500 \mathrm{~ms}$; increments of $10 \mathrm{pA}$ ) through the recording pipette and evaluated the changes in the membrane potential before and after bombesin application. In the presence of bombesin, the hyperpolarizing shifts in the membrane potential in response to the injection of negative current steps were reduced (Fig. 10D), and the current-voltage relationship showed a consistent alteration compared with control prebombesin conditions (Fig. 10D,E). A linear function was fitted to the current-voltage relationship, and a significant decrease in the slope was observed after bombesin application, consistent with a $22.4 \pm 5.7 \%$ reduction in the whole-cell input resistance $(n=8 ; p<0.05)$ (Fig. $10 D, E)$.

Depolarization coupled with a decrease in input resistance could be caused by the opening of sodium-dependent channels. 
(In TTX)

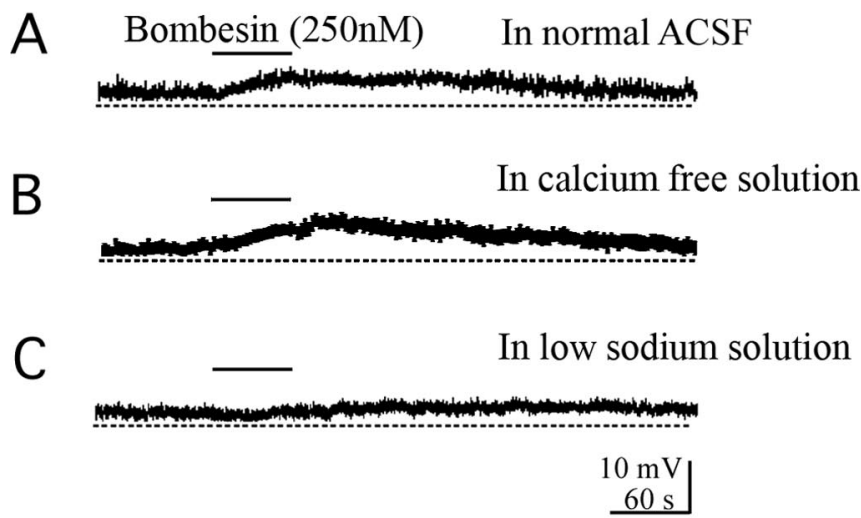

D

Control

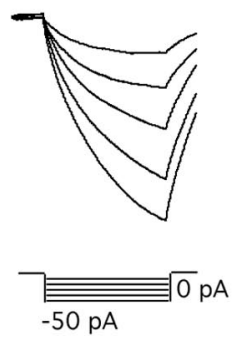

$\mathrm{F}$
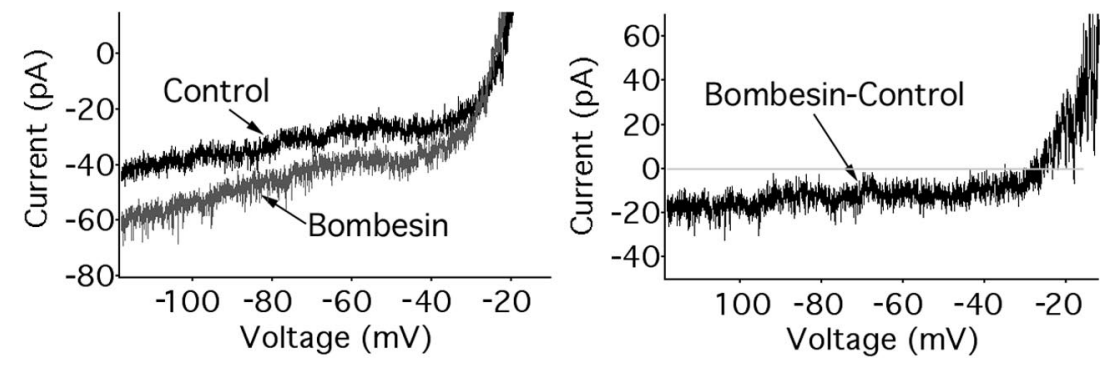

G

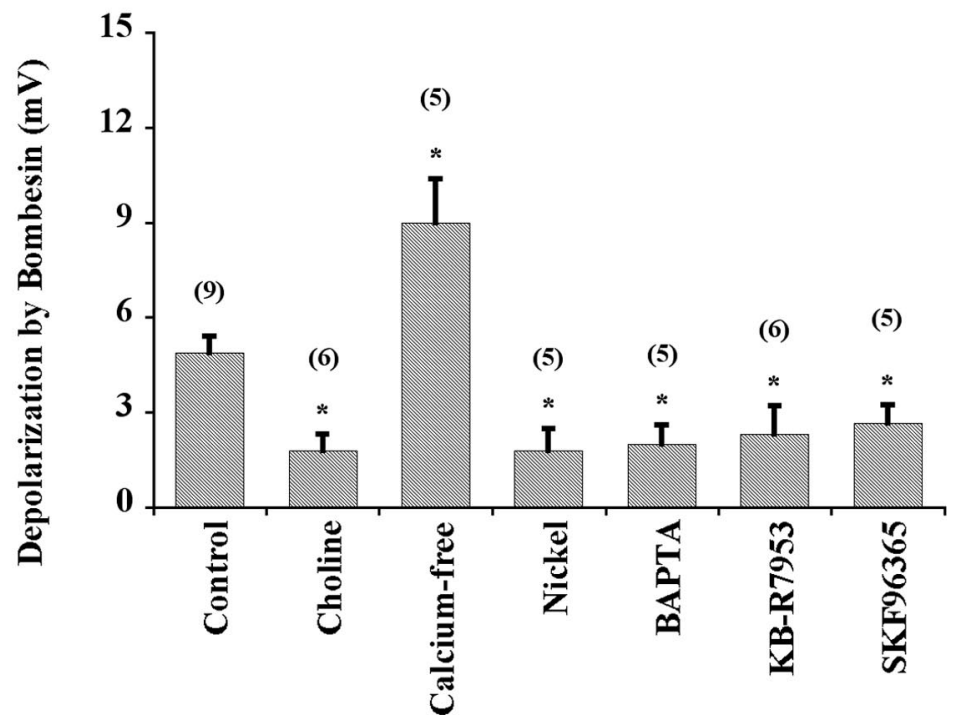

Figure 10. Direct effect of bombesin on NPY neurons. $A$, In the presence of TTX, bombesin depolarizes the membrane potential of an NPY neuron. $\boldsymbol{B}$, In a different NP4 cell, in $\mathbf{C a}^{2+}$-free ACSF, membrane depolarization by bombesin is increased. $\boldsymbol{C}$, When extracellular sodium is replaced by choline, membrane depolarization by bombesin is reduced. $\boldsymbol{D}$, Bombesin decreases the voltage response of NPY neurons after hyperpolarizing current steps (steps shown below response). $\boldsymbol{E}$, Graph shows the current-voltage
To test this hypothesis, we studied the $\mathrm{Na}^{+}$contribution to bombesin-induced depolarization. When $80 \%$ of the extracellular $\mathrm{NaCl}$ was replaced by an equimolar concentration of choline chloride, in the presence of TTX (Liu et al., 2002; Wu et al.,2004; Sekizawa and Bonham, 2006), the membrane depolarization by bombesin (250 nM) was significantly reduced to $1.8 \pm 0.5 \mathrm{mV}(n=6)$ (Fig. 10C,G). When the bombesin depolarizing effects in the presence of $\mathrm{NaCl}$ or choline chloride in the bath were compared, a statistically significant difference was detected $(p<0.05)$, suggesting that the bombesin actions on the membrane potential were dependent on extracellular $\mathrm{Na}^{+}$. In addition, when NPY neurons were held at $-60 \mathrm{mV}$ under voltage clamp, bombesin induced an inward current (data not shown). To determine the reversal potential of this bombesin-induced current, slow voltage ramp protocols (from -120 to $0 \mathrm{mV}$ for $5 \mathrm{~s}$ ) were delivered to the NPY cells. These experiments were done in the presence of TTX $(0.5 \mu \mathrm{M})$, CNQX $(10 \mu \mathrm{M})$, APV $(50$ $\mu \mathrm{M})$, and bicuculline (30 $\mu \mathrm{M})$ to block any synaptic contribution. The application of bombesin resulted in a consistent inward current, which showed a mean reversal potential near $-18.3 \pm 3.4 \mathrm{mV}$ in 7 of 10 cells tested (Fig. 10F). In the remaining 3 cells, the $I$ - $V$ lines remained parallel over the entire voltage range tested (data not shown).

With BAPTA $(10 \mathrm{~mm})$ in the pipette solution to lower available intracellular $\mathrm{Ca}^{2+}$, the bombesin (250 nM)-mediated depolarization of the NPY neuron was reduced from $4.9 \pm 0.5 \mathrm{mV}$ to $2.0 \pm 0.6 \mathrm{mV}$, a statistically significant reduction $(p<$ $0.05)$. In contrast, when a $\mathrm{Ca}^{2+}$-free extracellular buffer was used, the bombesinmediated depolarization was increased to $9.0 \pm 1.4 \mathrm{mV}$, a significant increase $(p<$ $0.05)$ (Fig. $10 B, G$ ), similar to that described for other nonselective cation currents (Hablitz et al., 1986; Xiong et al., 1997). We further tested the effect of SKF96365, a widely used TRP channel inhibitor (Halaszovich et al. 2000). With SKF96365 $(30 \mu \mathrm{M})$ in the bath the bombesin-mediated depolarization of the NPY neuron was reduced from $4.9 \pm 0.5$

relationship in the absence (white circle) and presence (filled circle) of bombesin. Bombesin evoked a decrease in the wholecell input resistance (slope). $\boldsymbol{F}$, Bombesin induced an inward current at voltages between -100 and $-20 \mathrm{mV}$ (left graph). The bombesin-induced current shows a reversal potential at $\sim-20 \mathrm{mV}$ (right graph). G, Mean membrane depolarization by bombesin in different conditions. The number of cells tested is in parentheses. 

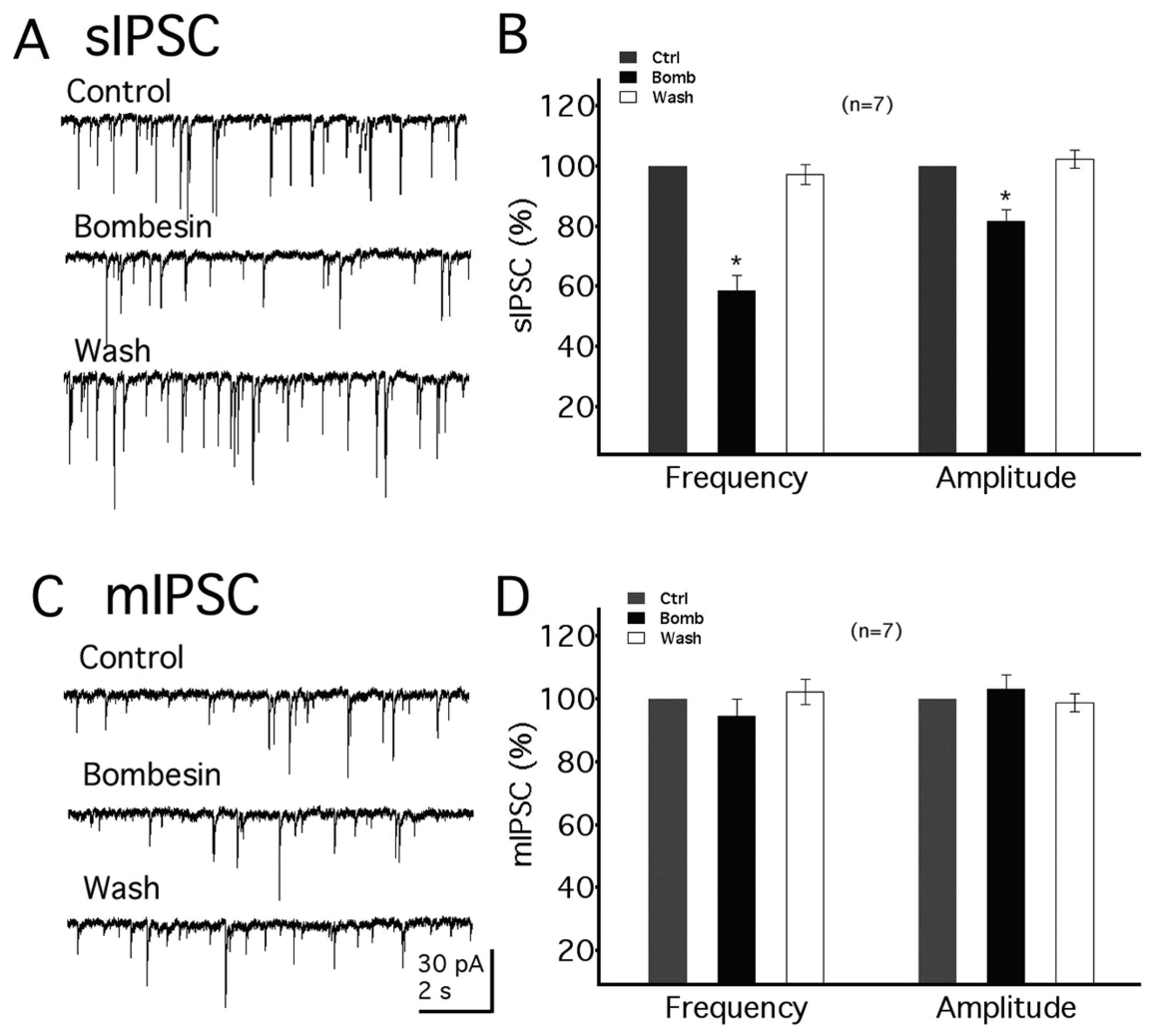

Figure 11. Bombesin modulates synaptic input. $\boldsymbol{A}$, Bombesin $(250 \mathrm{~nm})$ decreases sIPSC frequency. $\boldsymbol{B}$, Mean effect of bombesin on the frequency or amplitude of sIPSCs. Bombesin decreases both the frequency and amplitude of sIPSCs. $C$, Bombesin shows little effect on mIPSC frequency in the presence of $0.5 \mu \mathrm{m}$ TTX. D, Mean effect of bombesin on mIPSCs. Bombesin has no significant effect on the frequency or amplitude of mIPSC. The number of cells is shown in parentheses. Error bars indicate SEM. The asterisk $\left({ }^{*}\right)$ indicates statistical significance; $p<0.05$.

$\mathrm{mV}$ to $2.7 \pm 0.6 \mathrm{mV}$. These results suggest the excitatory effect of bombesin on NPY neurons is mediated by opening of sodiumdependent nonselective cationic channels (Fig. 10G).

In the experiments above, regardless of the blocker used, some residual depolarization remained, suggesting a second mechanism might be involved. We therefore tested the effects of external $\mathrm{Ni}^{2+}$, a nonselective blocker of the $\mathrm{Na}^{+} / \mathrm{Ca}^{2+}$ exchanger (Kimura et al., 1987; Eriksson et al., 2001), on bombesin-induced depolarization. $\mathrm{NiCl}_{2}(3 \mathrm{~mm})$ attenuated the depolarization by bombesin. With $\mathrm{NiCl}_{2}$ in the bath, the depolarization by bombesin was $2.4 \pm 0.7 \mathrm{mV}(n=5 ; p<0.05$ compared with the $4.9 \pm$ $0.5 \mathrm{mV}$ control depolarization). We next tested the effect of KBR7943, a selective $\mathrm{Na}^{+} / \mathrm{Ca}^{2+}$ exchanger blocker (Iwamoto et al., 1996), on bombesin induced depolarization. Application of KBR7943 $(60 \mu \mathrm{M})$ significantly attenuated the depolarization by bombesin (change of membrane potential in the presence of KB$\mathrm{R} 7943,2.3 \pm 0.9 \mathrm{mV} ; n=6 ; p<0.05)$ a statistically significant reduction (Fig. 10G).

These data suggest that bombesin-related peptides excite NPY neurons through two mechanisms, activation of the $\mathrm{Na}^{+} / \mathrm{Ca}^{2+}$ exchanger and opening of sodium-dependent nonselective cation channels, possibly TRP channels.

\section{Bombesin-like peptides modulate synaptic activity}

The actions of bombesin on postsynaptic currents in NPY neurons were examined next. As shown in Fig. 11, bombesin (250 $\mathrm{nM})$ decreased the frequency of spontaneous IPSCs by $41.4 \pm$ $5.0 \%(n=7, p<0.05)$ (Fig. 11A). Bombesin also decreased the amplitude of sIPSCs by $18.4 \pm 3.8 \%(n=7, p<0.05)($ Fig. $11 B)$.
These studies were performed in the presence of glutamate receptor antagonists CNQX $(10 \mu \mathrm{M})$ and AP5 $(50 \mu \mathrm{M})$ with a holding potential $-60 \mathrm{mV}$. To investigate whether bombesin decreases the GABA release by receptors on presynaptic terminals, the effect of bombesin on miniature IPSCs (mIPSCs) was studied in the presence of TTX to block action potentials. Bombesin (250 nM) showed no significant effect on the frequency or amplitude of mIPSCs (change in frequency and amplitude was $5.4 \pm 5.5 \%$ and $3.3 \pm 4.6 \%$, respectively, $n=7, p>0.5$ ) (Fig. $11 C, D$ ). These results suggest that bombesin decreases GABA release indirectly by acting on cells that projected to NPY neurons, and not by acting on presynaptic terminals.

\section{Bombesin excites POMC neurons}

In contrast to the orexigenic role of NPY cells, the POMC neurons of the arcuate nucleus are considered to serve the opposite function, and to reduce food intake. The effect of bombesin on GFP-identified arcuate POMC neurons was also studied. Similar to NPY cells, bombesin depolarized and excited POMC neurons. Bombesin (250 nM) increased the spike frequency by $97.5 \pm 21.4 \%$ in 12 of 15 cells $(p<0.05 ; n=12)$, with a mean depolarization of membrane potential of $6.3 \pm 0.5$ $\mathrm{mV}(p<0.05)$ (Fig. 12A). The remaining 3 neurons showed only a modest response to bombesin (change $<20 \%$ ). Taking all cells together, bombesin increased the spike frequency from $2.2 \pm 0.4 \mathrm{~Hz}$ by $83.0 \pm 19.5 \%$, with a mean depolarization of $5.2 \pm 0.6 \mathrm{mV}(n=15, p<0.05)$. In the presence of TTX in the bath, bombesin $(250 \mathrm{~nm})$ depolarized the membrane potential by $6.2 \pm 0.7 \mathrm{mV}(n=6, p<0.05)$ (Fig. 12C), suggesting a direct effect of the peptide.

NMB (250 nM) also excited POMC cells, with a mean depolarization of $5.9 \pm 0.6 \mathrm{mV}$ and an increase in spike frequency of $79.5 \pm 12.6 \%$ with seven of seven cells responding (Fig. 12B). The increase in spike frequency and amplitude of depolarization in response to bombesin and $\mathrm{NMB}$ was similar in the POMC cells recorded here to the NPY neuron data above. These results suggest that in addition to exciting NPY neurons, bombesin also exerts a direct excitatory action on POMC neurons, and that the magnitude of the excitatory effect was not significantly different from that found in NPY neurons.

\section{Discussion}

Robust response to GRP and NMB, but not to melanocortin agonist or antagonist

In a current model of central control of energy homeostasis, arcuate NPY neurons are considered to be orexigenic and provide an anabolic drive (Elias et al., 1999; Schwartz et al., 2000; Saper et al., 2002; Jobst et al., 2004) that counters the anorexigenic POMC neurons. We found little effect of three important neuromodulator receptor agonists that influence energy homeostasis, AgRP, the melanocortin receptor agonist MTII, and cannabinoids. The lack of response to MTII is consistent with earlier work (Rose- 
A

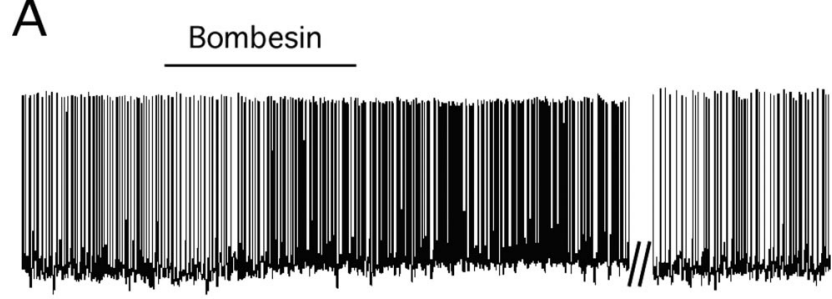

B

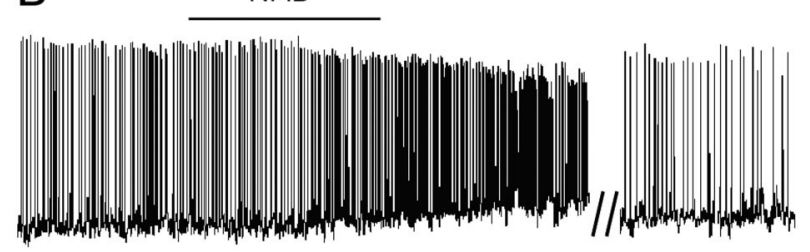

$30 \mathrm{mV}$

$30 \mathrm{~s}$

C

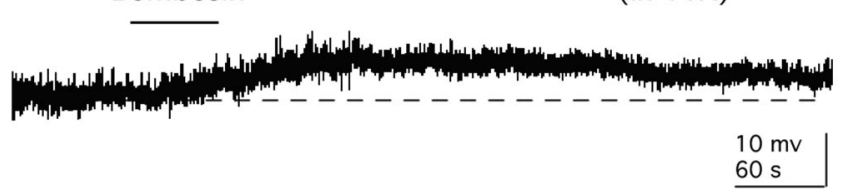

Figure 12. Bombesin and NMB excite POMC neurons. $A$, Bombesin ( $250 \mathrm{~nm}$ ) increases spike frequency in a POMC neuron. $B, N M B(250 \mathrm{nM})$ also increases spike frequency. $C$, In the presence of TTX, bombesin (250 nM) depolarizes the POMC cell, suggesting a direct effect.

berry et al., 2004). In contrast to the lack of a response to these critical modulators of energy homeostasis, bombesin-related peptides evoked a robust excitation of NPY neurons by direct postsynaptic action, sometimes accompanied by rapid spike bursts. The actions of bombesin-related peptides (BRPs) depolarized the membrane potential, resisted TTX block, were attenuated by substitution of choline for sodium, and the induced inward-current reversed $\sim-18 \mathrm{mV}$ suggesting either a nonselective cation channel or the sodium/calcium exchanger. In the presence of $\mathrm{Ni}^{2+}$, or KB-R7943, the effect was attenuated, suggesting activation of the sodium/calcium exchanger. In addition, the current was increased by lowering extracellular $\mathrm{Ca}^{2+}$ but reduced by adding BAPTA in the pipette, and blocked by the TRP channel blocker SKF96365, suggestive of a nonselective cation current. Together, these characteristics are most consistent with two mechanisms, activation of both a nonselective cation channel and of the sodium/calcium transporter.

Bombesin, GRP, and NMB all reduce food intake after systemic administration (Gibbs et al., 1979; Muurahainen et al., 1993; Gutzwiller et al., 1994; Ladenheim et al., 1994; Gonzalez et al., 2008). Our results showing robust excitatory actions of these peptides on the orexigenic NPY neurons may thus appear paradoxical at first. Available data suggest, however, that the satietyinducing action of systemic bombesin via the GRP-R may be primarily relayed via hindbrain sites such as the nucleus of the solitary tract (Flynn, 1989; Merali et al., 1993, 1998); similarly, the anorexigenic effects of NMB are blocked by fourth ventricular administration of an antagonist specific for the NMB-R (Ladenheim et al., 1997) and may be relayed via the vagus nerve, since this effect is not observed after primary sensory neurons are ablated (Ladenheim and Knipp, 2007).
Thus, it may be that the arcuate nucleus effects of BRPs studied here are not related to the previously described satiety effects of these peptides, and that the endogenous anatomical substrate for these actions represents a central BRP system. NMB and GRP are found in neurons in the hypothalamus and brain regions that project to the arcuate nucleus (Panula et al., 1982; Chronwall et al., 1985a; Wada et al., 1990; Mikkelsen et al., 1991); their receptors are also expressed in the medial hypothalamus (Zarbin et al., 1985; Wada et al., 1990, 1991, 1992; Moody and Merali, 2004). Our RT-PCR analysis of the arcuate nucleus showed expression of both the NMB and GRP receptors, consistent with earlier reports (Kamichi et al., 2005). RT-PCR analysis of NPY cells showed expression of the NMB receptor, but not GRP receptor. The lack of detectable GRP receptor suggests either a variant NMB-R that shows some response to GRP, or a level of GRP-R too low to detect by RT-PCR in these cells. Since the third BRP receptor (BRS-3) shows little sensitivity to peptides tested here (Gonzalez et al., 2008; Jensen et al., 2008), it is unlikely that this receptor is involved in the GRP/NMB responses. The NPY cells are involved not only in energy homeostasis, but also in endocrine regulation (McDonald and Koenig, 1993). The excitatory actions of GRP and bombesin may therefore relate to a role of these neuropeptides in modulating pituitary secretions.

Many neuromodulators have been reported to exert opposing effects on NPY and POMC cells by direct and indirect mechanisms. For instance, leptin excites POMC, but inhibits NPY neurons (Cowley et al., 2001; Coll et al., 2007). Similarly, ghrelin excites NPY neurons, but inhibits POMC neurons (Cowley et al., 2003). Foxo1, a mediator of insulin signaling, stimulates NPY, but inhibits POMC transcription (Kim et al., 2006). Serotonin inhibits NPY, but stimulates POMC cells (Heisler et al., 2002, 2006). In contrast to these opposing actions of other neuroactive substances, we find that in addition to excitatory responses in NPY neurons, BRPs also excite POMC neurons with responses of relatively similar strength. Given the rich innervation of preganglionic sympathetic spinal neurons provided by melanocortin fibers (Saper et al., 1976; Swanson and Kuypers, 1980; Elias et al., 1998), it is also possible that the excitation of POMC cells shown here relate to the potent central sympatho-excitatory effects of BRPs (Brown et al., 1977). The similar excitatory responses to BRPs by NPY and POMC cells suggest that BRPs may be involved in some broad activation of the arcuate nucleus energy homeostasis system, rather than selective activation of either orexigenic or anorexigenic systems. The same may be true for the arousal-promoting neuropeptide hypocretin/orexin, that similarly excites both NPY (van den Top et al., 2004) and POMC neurons (Acuna-Goycolea and van den Pol, 2009). BRPmediated direct excitation of the POMC cell appears to override the inhibition that would be caused by activation of inhibitory inputs to POMC cells from similarly stimulated NPY neurons (Cowley et al., 2001). Hypothetically, another possibility is that simultaneous activation of both NPY and POMC cells relates to some decision-making situation determining whether or not to feed under complex environmental input that may include food scarcity, circadian cycle, environmental threat or other factors that merit attention related to food intake.

\section{Renilla transgenic mouse}

The fluorescent signal in the transgenic mouse in the present study, based on Renilla GFP, was stronger than the signal from another reporter gene, tau-sapphire GFP (Roseberry et al., 2004) and was also much stronger than found in another mouse in which GFP driven by a mouse prion promoter was expressed in 
NPY neurons in the hilar region of the hippocampus ( $\mathrm{Fu}$ and van den Pol, 2007). There are several possible reasons for the strong fluorescence in the mouse described here: use of Renilla GFP, use of a long BAC sequence as the promoter, the use of free cytoplasmic GFP rather than attachment to the axonal protein tau, and selection of the mouse line that expressed GFP most robustly from a number of transgenic lines. Physiologically, NPY cells here expressing GFP appeared to show similar physiological characteristics to that previously reported using other means of detection or weaker fluorescence, including burst firing (Roseberry et al., 2004; van den Top et al., 2004; Acuna-Goycolea and van den Pol, 2005). These data support the view that expression of codoncorrected Renilla GFP does not appear to alter the physiological properties of those neurons that express it.

Cells expressing GFP under the control of the NPY promoter were observed in a wide distribution throughout the brain. As previously published accounts of the distribution of NPY peptide (Chronwall, 1985; Chronwall et al., 1985b; de Quidt and Emson, 1986; Ubink et al., 1994) and mRNA (Gehlert et al., 1987) in the brain have almost exclusively focused on the rat, these data, to our knowledge, offer the first systematic description of NPY neurons in the mouse brain. The distribution pattern of preproNPY mRNA-expressing cells (Allen Brain Altas: www.brain-map.org) strikingly mirror our findings of NPY-GFP distribution, further supporting the validity of this transgenic model. NPY promoterdriven GFP expression appears to identify clearly living NPY neurons. We could detect GFP-positive cells even in the lateral hypothalamus and dorsomedial nucleus, in which NPY is low but enhanced during certain metabolic challenges and during development (Grove et al., 2003); the presence of NPY neurons in these areas was confirmed with immunocytochemistry. We also readily detected fluorescent cells in the reticular thalamic nucleus, which can be difficult to visualize with some NPY antisera (Chronwall et al., 1985b; de Quidt and Emson, 1986), but can be observed with preproNPY in situ hybridization (Gehlert et al., 1987). We also found strong GFP expression in olfactory ensheathing cells in the olfactory nerve, confirming earlier reports of NPY in these glia (Ubink et al., 1994; Ubink and Hökfelt, 2000).

We corroborated the identity of the GFP-expressing cells with immunocytochemical staining for NPY, and with single-cell RTPCR. In the arcuate nucleus, NPY- and AgRP-immunoreactive cells were GFP positive, in agreement with the unique coexistence of these peptides (Broberger et al., 1998; Hahn et al., 1998). In contrast, the neighboring POMC cells did not express GFP. Together, these findings suggest that most NPY cells appear to express GFP, and that NPY immunoreactive cells were also GFP positive. Although we found no unexpected GFP expression in any brain region, we did not verify that all GFP cells in the CNS were NPY positive, and so further substantiation of the fidelity of GFP expression outside the hypothalamus will prove useful.

In summary, these data show a novel role for central bombesin-like peptides, with potent excitatory actions on the metabolic sensors of the brain including both NPY and POMC neurons in the arcuate nucleus. Furthermore, we provide a comprehensive map of NPY expression in the mouse brain, visualized by the powerful fluorescence of Renilla GFP.

\section{References}

Acuna-Goycolea C, van den Pol AN (2005) Peptide YY(3-36) inhibits both anorexigenic proopiomelanocortin and orexigenic neuropeptide $\mathrm{Y}$ neurons: implications for hypothalamic regulation of energy homeostasis. J Neurosci 25:10510-10519.
Acuna-Goycolea C, van den Pol AN (2009) Neuroendocrine proopiomelanocortin neurons are excited by hypocretin/orexin. J Neurosci 29:1503-1515.

Acuna-Goycolea C, Tamamaki N, Yanagawa Y, Obata K, van den Pol AN (2005) Mechanisms of neuropeptide Y, peptide YY, and pancreatic polypeptide inhibition of identified green fluorescent protein-expressing GABA neurons in the hypothalamic neuroendocrine arcuate nucleus. J Neurosci 25:7406-7419.

Bai FL, Yamano M, Shiotani Y, Emson PC, Smith AD, Powell JF, Tohyama M (1985) An arcuato-paraventricular and -dorsomedial hypothalamic neuropeptide Y-containing system which lacks noradrenaline in the rat. Brain Res 331:172-175.

Batterham RL, Cowley MA, Small CJ, Herzog H, Cohen MA, Dakin CL, Wren AM, Brynes AE, Low MJ, Ghatei MA, Cone RD, Bloom SR (2002) Gut hormone $\mathrm{PYY}_{3-36}$ physiologically inhibits food intake. Nature 418:650-654.

Broberger C, De Lecea L, Sutcliffe JG, Hökfelt T (1998) Hypocretin/orexinand melanin concentrating hormone-expressing cells form distinct populations in the rodent lateral hypothalamus: relationship to the neuropeptide $\mathrm{Y}$ and agouti gene-related protein systems. J Comp Neurol 402:460-474.

Broberger C, Visser TJ, Kuhar MJ, Hökfelt T (1999) Neuropeptide Y innervation and neuropeptide-Y-Y1-receptor-expressing neurons in the paraventricular hypothalamic nucleus of the mouse. Neuroendocrinology 70:295-305.

Brown MR, Rivier J, Vale W (1977) Bombesin affects the central nervous system to produce hyperglycemia in rats. Life Sci 21:1729-1734.

Chen G, van den Pol AN (1996) Multiple NPY receptors coexist in pre- and postsynaptic sites: inhibition of GABA release in isolated self-innervating SCN neurons. J Neurosci 16:7711-7724.

Chronwall BM (1985) Anatomy and physiology of the neuroendocrine arcuate nucleus. Peptides 6 [Suppl 2]:1-11.

Chronwall BM, Pisano JJ, Bishop JF, Moody TW, O’Donohue TL (1985a) Biochemical and histochemical characterization of ranatensin immunoreactive peptides in rat brain: lack of coexistence with bombesin/GRP. Brain Res 338:97-113.

Chronwall BM, DiMaggio DA, Massari VJ, Pickel VM, Ruggiero DA, O'Donohue TL. (1985b) The anatomy of neuropeptide-Y-containing neurons in rat brain. Neuroscience 15:1159-1181.

Coll AP, Farooqi IS, O'Rahilly S (2007) The hormonal control of food intake. Cell 129:251-262.

Colmers WF, Wahlestedt C (1993) The biology of neuropeptide Y and related peptides. Totowa, NJ: Humana.

Colmers WF, Klapstein GJ, Fournier A, St-Pierre S, Treherne KA (1991) Presynaptic inhibition by neuropeptide $\mathrm{Y}$ in rat hippocampal slice in vitro is mediated by a Y2 receptor. Br J Pharmacol 102:41-44.

Cone RD (2006) Studies on the physiological functions of the melanocortin system. Endocr Rev 27:736-749.

Cota D, Tschöp MH, Horvath TL, Levine AS (2006) Cannabinoids, opioids and eating behavior: the molecular face of hedonism? Brain Res Rev 51:85-107.

Cowley MA, Smart JL, Rubinstein M, Cerdán MG, Diano S, Horvath TL, Cone RD, Low MJ (2001) Leptin activates anorexigenic POMC neurons through a neural network in the arcuate nucleus. Nature 411:480-484.

Cowley MA, Smith RG, Diano S, Tschöp M, Pronchuk N, Grove KL, Strasburger CJ, Bidlingmaier M, Esterman M, Heiman ML, Garcia-Segura LM, Nillni EA, Mendez P, Low MJ, Sotonyi P, Friedman JM, Liu H, Pinto S, Colmers WF, Cone RD, Horvath TL (2003) The distribution and mechanism of action of ghrelin in the CNS demonstrates a novel hypothalamic circuit regulating energy homeostasis. Neuron 37:649-661.

de Quidt ME, Emson PC (1986) Distribution of neuropeptide Y-like immunoreactivity in the rat central nervous system-II. Immunohistochemical analysis. Neuroscience 18:545-618.

Elias CF, Lee C, Kelly J, Aschkenasi C, Ahima RS, Couceyro PR, Kuhar MJ, Saper CB, Elmquist JK (1998) Leptin activates hypothalamic CART neurons projecting to the spinal cord. Neuron 21:1375-1385.

Elias CF, Aschkenasi C, Lee C, Kelly J, Ahima RS, Bjorbaek C, Flier JS, Saper CB, Elmquist JK (1999) Leptin differentially regulates NPY and POMC neurons projecting to the lateral hypothalamic area. Neuron 23:775-786.

Elmquist JK, Elias CF, Saper CB (1999) From lesions to leptin: hypothalamic control of food intake and body weight. Neuron 22:221-232.

Eriksson KS, Sergeeva O, Brown RE, Haas HL (2001) Orexin/hypocretin 
excites the histaminergic neurons of the tuberomammillary nucleus. J Neurosci 21:9273-9279.

Flynn FW (1993) Fourth ventricular injection of selective bombesin receptor antagonists facilitates feeding in rats. Am J Physiol 264:R218-R221.

Flynn FW (1989) Fourth ventricle bombesin injection suppresses ingestive behaviors in rats. Am J Physiol 256:R590-R596.

Fu LY, van den Pol AN (2007) GABA excitation in mouse hilar neuropeptide Y neurons. J Physiol 579:445-464.

Fu LY, van den Pol AN (2008) Agouti-related peptide and MC3/4 receptor agonists both inhibit excitatory hypothalamic ventromedial nucleus neurons. J Neurosci 28:5433-5449.

Fu LY, Acuna-Goycolea C, van den Pol AN (2004) Neuropeptide Y inhibits hypocretin /orexin neurons by multiple presynaptic and postsynaptic mechanisms: tonic depression of the hypothalamic arousal system. J Neurosci 24:8741-8751.

Gao XB, van den Pol AN (2001) Melanin concentrating hormone depresses synaptic activity of glutamate and GABA neurons from rat lateral hypothalamus. J Physiol 533:237-252.

Gehlert DR, Chronwall BM, Schafer MP, O’Donohue TL (1987) Localization of neuropeptide $\mathrm{Y}$ messenger ribonucleic acid in rat and mouse brain by in situ hybridization. Synapse 1:25-31.

Gibbs J, Fauser DJ, Rowe EA, Rolls BJ, Rolls ET, Maddison SP (1979) Bombesin suppresses feeding in rats. Nature 282:208-210.

Gonzalez N, Moody TW, Igarashi H, Ito T, Jensen RT (2008) Bombesinrelated peptides and their receptors: recent advances in their role in physiology and disease states. Curr Opin Endocrinol Diabetes Obes 15:58-64.

Grove KL, Chen P, Koegler FH, Schiffmaker A, Susan Smith M, Cameron JL (2003) Fasting activates neuropeptide $Y$ neurons in the arcuate nucleus and the paraventricular nucleus in the rhesus macaque. Mol Brain Res 113:133-138.

Gutzwiller JP, Drewe J, Hildebrand P, Rossi L, Lauper JZ, Beglinger C (1994) Effect of intravenous human gastrin-releasing peptide on food intake in humans. Gastroenterology 106:1168-1173.

Hablitz JJ, Heinemann U, Lux, H.-D (1986) Step reductions in extracellular $\mathrm{Ca}^{2+}$ activate a transient inward current in chick dorsal root ganglion cells. Biophys J, 50:753-757.

Hahn TM, Breininger JF, Baskin DG, Schwartz MW (1998) Coexpression of Agrp and NPY in fasting-activated hypothalamic neurons. Nat Neurosci 1:271-272.

Halaszovich CR, Zitt C, Jungling E, Luckhoff A (2000) Inhibition of TRP3 channels by lanthanides. Block from the cytosolic side of the plasma membrane. J Biol Chem 275:37423-37428.

Heisler LK, Cowley MA, Tecott LH, Fan W, Low MJ, Smart JL, Rubinstein M, Tatro JB, Marcus JN, Holstege H, Lee CE, Cone RD, Elmquist JK (2002) Activation of central melanocortin pathways by fenfluramine. Science 297:609-611.

Heisler LK, Jobst EE, Sutton GM, Zhou L, Borok E, Thornton-Jones Z, Liu HY, Zigman JM, Balthasar N, Kishi T, Lee CE, Aschkenasi CJ, Zhang CY, Yu J, Boss O, Mountjoy KG, Clifton PG, Lowell BB, Friedman JM, Horvath T, Butler AA, Elmquist JK, Cowley MA (2006) Serotonin reciprocally regulates melanocortin neurons to modulate food intake. Neuron 51:239-249.

Hentges ST, Low MJ, Williams JT (2005) Differential regulation of synaptic inputs by constitutively released endocannabinoids and exogenous cannabinoids. J Neurosci 25:9746-9751.

Hogan B, Costantini F, Lacey E (1986) Introduction of new genetic information into the developing mouse embryo. In: Manipulating the mouse embryo, pp. 153-197. Cold Spring Harbor, NY: Cold Spring Harbor Laboratory.

Iwamoto T, Watano T, Shigekawa M (1996) A novel isothiourea derivative selectively inhibits the reverse mode of $\mathrm{Na}^{+} / \mathrm{Ca}^{2+}$ exchange in cells expressing NCX1. J Biol Chem 271:22391-22397.

Jensen RT, Battey JF, Spindel ER, Benya RV (2008) International union of pharmacology. LXVIII Mammalian bombesin receptors: nomenclature, distribution, pharmacology, signaling, and functions in normal and disease states. Pharmacol Rev 60:1-42.

Jobst EE, Enriori PJ, Cowley MA (2004) The electrophysiology of feeding circuits. Trends Endocrinol Metab 15:488-499.

Kamichi S, Wada E, Aoki S, Sekiguchi M, Kimura I, Wada K (2005) Immunohistochemical localization of gastrin-releasing peptide receptor in the mouse brain. Brain Res 1032:162-170.

Kang L, Routh VH, Kuzhikandathil EV, Gaspers LD, Levin BE (2004) Phys- iological and molecular characteristics of rat hypothalamic ventromedial nucleus glucosensing neurons. Diabetes 53:549-559.

Kim MS, Pak YK, Jang PG, Namkoong C, Choi YS, Won JC, Kim KS, Kim SW, Kim HS, Park JY, Kim YB, Lee KU (2006) Role of hypothalamic Foxo1 in the regulation of food intake and energy homeostasis. Nat Neurosci 9:901-906.

Kimura J, Miyamae S, Noma A (1987) Identification of sodium-calcium exchange current in single ventricular cells of guinea-pig. J Physiol 384: $199-222$.

Kopp J, Xu ZQ, Zhang X, Pedrazzini T, Herzog H, Kresse A, Wong H, Walsh JH, Hökfelt T (2002) Expression of the neuropeptide Y Y1 receptor in the CNS of rat and of wild-type and Y1 receptor knock-out mice. Focus on immunohistochemical localization. Neuroscience 111:443-532.

Kumarnsit E, Johnstone LE, Leng G (2003) Actions of neuropeptide Y and growth hormone secretagogues in the arcuate nucleus and ventromedial hypothalamic nucleus. Eur J Neurosci 17:937-944.

Ladenheim EE, Knipp S (2007) Capsaicin treatment differentially affects feeding suppression by bombesin-like peptides. Physiol Behav 91:36-41.

Ladenheim EE, Taylor JE, Coy DH, Moran TH (1994) Blockade of feeding inhibition by neuromedin B using a selective receptor antagonist. Eur J Pharmacol 271:R7-R9.

Ladenheim EE, Taylor JE, Coy DH, Carrigan TS, Wohn A, Moran TH (1997) Caudal hindbrain neuromedin B-preferring receptors participate in the control of food intake. Am J Physiol 272:R433-R437.

Lee EC, Yu D, Martinez de Velasco J, Tessarollo L, Swing DA, Court DL, Jenkins NA, Copeland NG (2001) A highly efficient Escherichia colibased chromosome engineering system adapted for recombinogenic targeting and subcloning of BAC DNA. Genomics 73:56-65.

Lin JY, Pan JT (1994) Stimulatory effects of bombesin-like peptides on hypothalamic arcuate neurons in rat brain slices. Brain Res Bull 35:241-246.

Liu RJ, van den Pol AN, Aghajanian GK (2002) Hypocretins (orexins) regulate serotonin neurons in the dorsal raphe nucleus by excitatory direct and inhibitory indirect actions. J Neurosci 22:9453-9464.

McDonald JK, Koenig JI (1993) Neuropeptide Y actions on reproductive and endocrine functions. In: The biology of Neuropeptide $\mathrm{Y}$ and related peptides (Colmers WF and Wahlestedt C, eds), pp 419-456. Totowa NJ: Humana.

Merali Z, Moody TW, Coy D (1993) Blockade of brain bombesin/GRP receptors increases food intake in satiated rats. Am J Physiol 264:R1031-R1034.

Merali Z, McIntosh J, Kent P, Michaud D, Anisman H (1998) Aversive and appetitive events evoke the release of corticotropin-releasing hormone and bombesin-like peptides at the central nucleus of the amygdala. J Neurosci 18:4758-4766.

Mikkelsen JD, Larsen PJ, O’Hare MM, Wiegand SJ (1991) Gastrin releasing peptide in the rat suprachiasmatic nucleus: an immunohistochemical, chromatographic and radioimmunological study. Neuroscience 40:55-66.

Moody TW, Merali Z (2004) Bombesin-like peptides and associated receptors within the brain: distribution and behavioral implications. Peptides 25:511-520.

Muurahainen NE, Kissileff HR, Pi-Sunyer FX (1993) Intravenous infusion of bombesin reduces food intake in humans. Am J Physiol 264:R350-R354.

Myojin T, Kitamura N, Hondo E, Baltazar ET, Pearson GT, Yamada J (2000) Immunohistochemical localization of neuropeptides in bovine pancreas. Anat Histol Embryol 29:167-172.

Ohki-Hamazaki H, Watase K, Yamamoto K, Ogura H, Yamano M, Yamada K, Maeno H, Imaki J, Kikuyama S, Wada E, Wada K (1997) Mice lacking bombesin receptor subtype-3 develop metabolic defects and obesity. Nature 390:165-169.

Panula P, Yang HY, Costa E (1982) Neuronal location of the bombesin-like immunoreactivity in the central nervous system of the rat. Regul Pept 4:275-283.

Paxinos G and Franklin KB (2001) The mouse brain in stereotaxic coordinates. Amsterdam: Elsevier.

Pinto S, Roseberry AG, Liu H, Diano S, Shanabrough M, Cai X, Friedman JM, Horvath TL (2004) Rapid rewiring of arcuate nucleus feeding circuits by leptin. Science 304:110-115.

Rhim H, Kinney GA, Emmerson PJ, Miller RJ (1997) Regulation of neurotransmission in the arcute nucleus of the rat by different neuropeptide $Y$ receptors. J Neurosci 17:2980-2989. 
Roseberry AG, Liu H, Jackson AC, Cai X, Friedman JM (2004) Neuropeptide Y-mediated inhibition of proopiomelanocortin neurons in the arcuate nucleus shows enhanced desensitization in ob/ob mice. Neuron 41:711-722.

Saper CB, Loewy AD, Swanson LW, Cowan WM (1976) Direct hypothalamo-autonomic connections. Brain Res 117:305-312.

Saper CB, Chou TC, Elmquist JK (2002) The need to feed: homeostatic and hedonic control of eating. Neuron 36:199-211.

Schwartz MW, Woods SC, Porte D Jr, Seeley RJ, Baskin DG (2000) Central nervous system control of food intake. Nature 404:661-671.

Seeley RJ, Woods SC (2003) Monitoring of stored and available fuel by the CNS: implications for obesity. Nat Rev Neurosci 4:901-909.

Sekizawa S, Bonham AC (2006) Group I metabotropic glutamate receptors on second-order baroreceptor neurons are tonically activated and induce a Na+-Ca2 + exchange current. J Neurophysiol 95:882-892.

Stanley BG, Leibowitz SF (1985) NPY injected in the paraventricular hypothalamus: a powerful stimulant of feeding behavior. Proc Natl Acad Sci U S A 82:3940-3943.

Swanson LW, Kuypers HG (1980) A direct projection from the ventromedial nucleus and retrochiasmatic area of the hypothalamus to the medulla and spinal cord of the rat. Neurosci Lett 17:307-312.

Tsushima H, Mori M (2005) Mechanisms underlying anorexia after microinjection of bombesin into the lateral cerebroventricle. Pharmacol Biochem Behav 80:289-296.

Ubink R, Hökfelt T (2000) Expression of neuropeptide Y in olfactory ensheathing cells during prenatal development. J Comp Neurol 423:13-22.

Ubink R, Halasz N, Zhang X, Dagerlind A, Hökfelt T (1994) Neuropeptide tyrosine is expressed in ensheathing cells around the olfactory nerves in the rat olfactory bulb. Neuroscience 60:709-726.

van den Pol AN, Obrietan K, Chen G, Belousov AB (1996) Neuropeptide
Y-mediated long-term depression of excitatory activity in suprachiasmatic nucleus neurons. J Neurosci 16:5883-5895.

van den Pol AN, Acuna-Goycolea C, Clark KR, Ghosh PK (2004) Physiological properties of hypothalamic $\mathrm{MCH}$ neurons identified with selective expression of reporter gene after recombinant virus infection. Neuron 42:635-652.

van den Top M, Lee K, Whyment AD, Blanks AM, Spanswick D (2004) Orexigen-sensitive NPY/AgRP pacemaker neurons in the hypothalamic arcuate nucleus. Nat Neurosci 7:493-494.

Wada E, Way J, Lebacq-Verheyden AM, Battey JF (1990) Neuromedin B and gastrin-releasing peptide mRNAs are differentially distributed in the rat nervous system. J Neurosci 10:2917-2930.

Wada E, Way J, Shapira H, Kusano K, Lebacq-Verheyden AM, Coy D, Jensen R, Battery J (1991) cDNA cloning, characterization and brain regionspecific expression of a neuromedin-B-preferring bombesin receptor. Neuron 6:421-430

Wada E, Wray S, Key S, Battey J (1992) Comparison of gene expression for two distinct bombesin receptor subtypes in postnatal rat central nervous system. Mol Cell Neurosci 3:446-460.

Wu M, Zaborszky L, Hajszan T, van den Pol AN, Alreja M (2004) Hypocretin/orexin innervation and excitation of identified septohippocampal cholinergic neurons. J Neurosci 24:3527-3536.

Xiong Z, Lu W, MacDonald JF (1997) Extracellular calcium sensed by a novel cation channel in hippocampal neurons. Proc Natl Acad Sci U S A 94:7012-7017.

Zarbin MA, Kuhar MJ, O’Donohue TL, Wolf SS, Moody TW (1985) Autoradiographic localization of (125I-Tyr4)bombesin binding sites in rat brain. J Neurosci 5:429-437.

Zhang C, Bosch MA, Levine JE, Rønnekleiv OK, Kelly MJ (2007) Gonadotropin-releasing hormone neurons express K(ATP) channels that are regulated by estrogen and responsive to glucose and metabolic inhibition. J Neurosci 27:10153-10164. 